\title{
Impacts of the East Asian Winter Monsoon and Local Sea Surface Temperature on Heavy Snowfall over the Yeongdong Region
}

\author{
JINEUN KIM \\ School of Urban and Environmental Engineering, Ulsan National Institute of Science and Technology, and Safety \\ Research Division, National Disaster Management Research Institute, Ulsan, South Korea \\ DONGHYUCK YOON AND DONG-HYUN CHA \\ School of Urban and Environmental Engineering, Ulsan National Institute of Science and Technology, Ulsan, South Korea \\ YONGHAN CHOI \\ School of Urban and Environmental Engineering, Ulsan National Institute of Science and Technology, Ulsan, and \\ Korea Polar Research Institute, Incheon, South Korea \\ JOOWAN KIM \\ Department of Atmospheric Science, Kongju National University, Gongju, South Korea \\ SEOK-WOO SON \\ School of Earth and Environmental Sciences, Seoul National University, Seoul, South Korea
}

(Manuscript received 25 June 2018, in final form 29 May 2019)

\begin{abstract}
This research investigates the impact of local sea surface temperature (SST) on the 2-month (January and February) accumulated snowfall over the Yeongdong (YD) region. The YD region is strongly affected by synoptic-scale factors such as the East Asian winter monsoon (EAWM). The relationships of snowfall over the YD region to the EAWM and local SST are examined based on observational analyses and sensitivity experiments using a regional climate model. In the sensitivity experiments, local SST is replaced with the 33-yr mean winter SST (1982-2014). The observational analysis shows that both the synoptic environment and local SST are important factors for the occurrence of anomalous heavy snowfall over the YD region. The favorable synoptic environments can be characterized by eastward expansion of the Siberian high over Manchuria and corresponding enhancement of easterly anomalies over the YD region. These conditions are more frequently observed during the weak EAWM years than during the strong EAWM. Furthermore, warm SST over the East Sea contributes to heavy snowfall over the YD region by providing heat and moisture in the lower troposphere, which are important sources of energy for the formation of heavy snowfall. Warm SST anomalies over the East Sea enhance low-level moisture convergence over the YD region, while cold SST anomalies lead to reduced moisture convergence. Sensitivity experiments indicate that local SST can significantly affect snowfall amount over the YD region when the synoptic environments are favorable. However, without these synoptic conditions (expansion of the Siberian high and easterly inflow), the impact of local SST on the snowfall over the YD region is not significant.
\end{abstract}

\section{Introduction}

The 2018 Pyeongchang Winter Olympic Games were held in South Korea in the Yeongdong (YD) region. The YD region, on the eastern coast of South Korea,

Corresponding author: Dong-Hyun Cha, dhcha@unist.ac.kr frequently suffers from severe snowfall due to the combined effects of the steep orography (Taebaek Mountains) and its proximity to the ocean (Chung et al. 2004; Kim et al. 2005; Kim and Chung 2006; Lee et al. 2006; Han and Lee 2007; Lee and Kim 2008). Several observational studies have investigated the synoptic characteristics and physical mechanisms of snowfall 
over the YD region (Jhun et al. 1994; Lee and Kim 2008; Lee and Kim 2009; Jung et al. 2012; Jung et al. 2014). YD snowfall is generally known to follow the synoptic processes listed below. First, the eastward expansion of the Siberian high to Manchuria leads to cold advection and easterly wind over the East Sea (the Sea of Japan) and the YD region. Subsequently, the cold advection over the ocean enhances heat and moisture fluxes from the ocean surface, which results in a thermal inversion in the lower troposphere and development of convective clouds. Finally, the convective clouds developed over the ocean are transported into the coastal region by the easterly wind. In addition to the extended Siberian high, low pressure systems passing over the southern part of the Korean Peninsula could cause heavy snowfall over the YD region. Low pressure systems, after passing over the East China Sea, result in southeasterly flow over the YD region that transports a large amount of water vapor from the ocean. Therefore, the formation of an easterly wind either by the Siberian high or by a low pressure system is a necessary synoptic condition for heavy snowfall over the YD region. Choi and Kim (2010) further quantified these impacts and suggested that snowfall related to the surge of the Siberian high occurs twice more frequently than snowfall associated with low-pressure systems passing through the southern part of the Korean Peninsula.

Although the synoptic circulation patterns provide important background for the YD snowfall, regional or local factors also play significant roles. Orographic lifting due to the Taebaek Mountain and transport of moisture and heat from the nearby ocean are important processes for the heavy snowfall over the YD region. Recent studies focus on these local factors to explain the reason why the YD region experiences more frequent and heavier snowfall than other areas (Lee and Lee 1994; Jhun et al. 1994; Lee and Kim 2008; Lee and Kim 2009; Lee et al. 2010; Cho and Kwon 2012; Jung et al. 2012; Cho et al. 2015). Numerical experiments have also been used to test the idea. Lee and Kim (2008) showed that the topographic effect is the key factor in the formation of heavy snowfall in the YD region using a numerical simulation with removed topography over the Taebaek Mountains. Lee and Lee (1994) also showed that the height of the topography significantly affects snowfall amounts over the YD region. The local effect of the East Sea has also been investigated (Kang and Ahn 2008; Cha et al. 2011b; Cho and Kwon 2012; Jung et al. 2012). Particularly, Cha et al. (2011b) suggested that sea surface temperature (SST) over the East Sea is a significant factor for severe snowfall over the YD region, which controls moisture and heat fluxes from the ocean. They showed that warm SSTs could enhance convection and YD snowfall by modifying vertical heat and moisture fluxes in the atmospheric boundary layer. Jung et al. (2012) also showed that increasing SST tends to enhance precipitation, because warmer SSTs can provide higher sensible and latent heat fluxes. Several other studies indicated a significant role of a frictional convergence of moisture due to differences in the surface roughness between the ocean and land, which was identified as an important factor in determining the occurrence of snowfall (Kristovich and Spinar 2005; Miles and Verlinde 2005; Ninomiya et al. 2006).

Clearly, snowfall amounts over the YD region can be simultaneously affected by the synoptic environment and regional factors, and their interaction could also play an important role in setting interannual variation of snowfall in the YD region. Therefore, we investigate these factors and YD snowfall with a particular focus on their interannual variability. Because the interannual variability of the Siberian high, which provides the dominant synoptic environment leading to snowfall over the YD region, has a clear correlation with the intensity of the East Asian winter monsoon (EAWM; Chang et al. 1979; Chang and Lau 1982; Ding and Krishnamurti 1987; Murakami 1987; Chen et al. 2000; Wu and Wang 2002; Jhun and Lee 2004), we adopt a EAWM index to classify synoptic background for YD snowfall. Although a number of studies have investigated the relationship of the EAWM with variability in winter precipitation (Xin et al. 2006; Fu et al. 2008; Zhou 2011), surface temperature (Zhou and Wang 2008), and cold waves (Lu and Chang 2009) in East Asia, few studies have examined its influence on snowfall. Furthermore, the impact of local SST on the interannual variability of snowfall has rarely been examined. Various SST experiments have only been performed considering short-term case studies of individual heavy snow events (Lee and Ryu 2010; Cha et al. 2011b; Cho and Kwon 2012; Jung et al. 2012; Kim and Jin 2016).

The objective of this study is identifying the relative contributions of the EAWM and local SST on interannual variability of snowfall over the YD region using relatively long observational records (33 years). A series of sensitivity experiments is also conducted to support the results found from the observation analyses. A high-resolution regional climate model (RCM) is used for the sensitivity experiment because it can provide detailed information on extreme weather and climate compared to low-resolution global climate models (Cha et al. 2011a; Lee et al. 2013).

Section 2 describes the data, the model, and the experimental design. Section 3 analyzes how interannual variability of snowfall over the YD region relates to the EAWM and local SST. The impact of the synoptic 
environment and local SST on snowfall over the YD region is presented in section 4. Finally, section 5 presents a summary and conclusions.

\section{Data and model description}

\section{a. Data description}

Three gridded datasets are used in this research. Zonal wind speed at $300 \mathrm{hPa}$, which is used for the monsoon index calculation, sea level pressure, and zonal wind speed at $850 \mathrm{hPa}$ are obtained from the European Centre for Medium-Range Weather Forecasts (ECMWF) interim reanalysis (ERA-Interim) daily data (Dee et al. 2011) with $0.75^{\circ} \times 0.75^{\circ}$ horizontal resolution. In addition, SST is acquired from the Optimum Interpolation Sea Surface Temperature (OISST) monthly data (Reynolds et al. 2007; Banzon et al. 2016), which have $0.25^{\circ} \times 0.25^{\circ}$ horizontal resolution and are produced by the National Oceanic and Atmospheric Administration (NOAA). The Woods Hole Oceanography Institute objectively analyzed air-sea fluxes (OAFlux) data (Yu et al. 2008) are used for the analysis of latent heat flux at the ocean surface.

Observations of snowfall amount for the YD region are obtained from four meteorological stations through the National Climate Data Service System (NCDSS) of the Korea Meteorological Administration (KMA). Four stations are Sokcho (SC), Daegwallyeong (DG), Gangneung (GN), and Uljin (UJ) where daily snowfall data are available as far back as 1982. All datasets used in this study cover 33 years (1982-2014). In this study, the winter season is defined as January and February because most snowfall events over the YD region occur in those two months, and only data from January and February are used in the experiments and analysis.

\section{b. Model and experimental design}

The RCM used in this study is the Weather Research and Forecasting (WRF) Model (version 3.7.1) described by Skamarock et al. (2008). The WRF Model is the most popular mesoscale numerical model for both atmospheric research and operational forecasting. The physical parameterizations chosen for the SST sensitivity experiments are the Dudhia shortwave radiation scheme (Dudhia 1989), the RRTM longwave radiation scheme (Mlawer et al. 1997), the Noah land surface model (Chen and Dudhia 2001), the MM5 similarity surface-layer scheme (Beljaars 1995), and the KainFritsch cumulus parameterization scheme (Kain 2004). The Lin et al. scheme (Lin et al. 1983) and the Asymmetric Convection Model 2 scheme (Pleim 2007) are

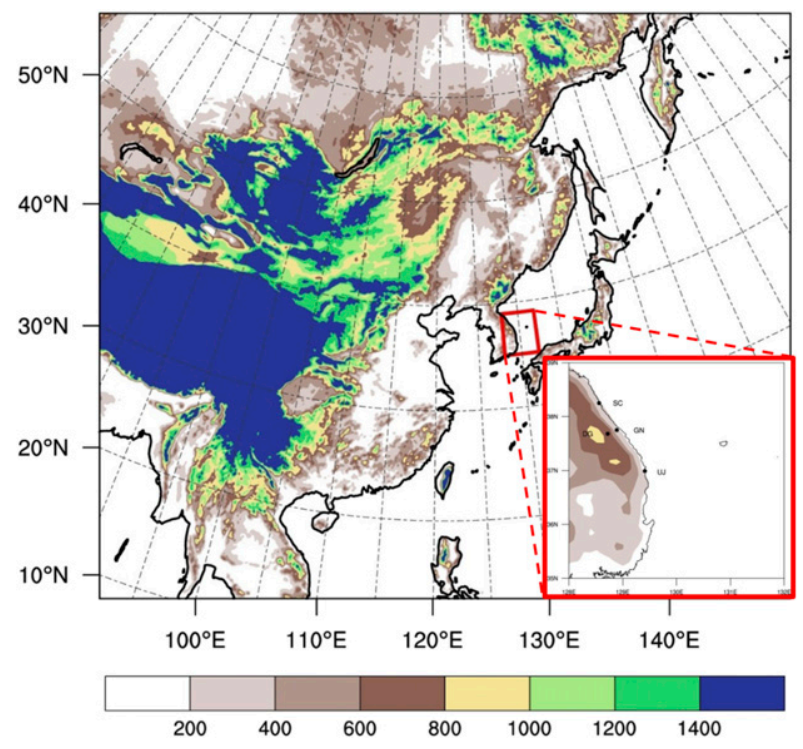

FIG. 1. Domain configuration with model terrain height (m).

selected as the microphysics scheme and the planetary boundary layer parameterization, respectively.

Cohen et al. (2015) investigated the effects of physical parameterizations on the simulation of snow events with the goal of improving the accuracy of snowfall simulations. Fernández-González et al. (2015) analyzed the influence of different parameterization schemes. Their results indicated that the planetary boundary layer and microphysics schemes have strong influences on surface precipitation patterns. Microphysical processes control the formation and growth of cloud droplets and ice crystals and their fallout as precipitation, and planetary boundary layer processes deal with the vertical transport of heat, moisture, and momentum and low-level cloud development. The WRF Model offers multiple options for most physical parameterizations, enabling users to optimize the model for a variety of spatial and temporal resolutions and climatologically different regions. Therefore, before beginning the present study, we conducted sensitivity experiments to determine the optimal combination of microphysics and planetary boundary layer schemes.

The model domain covers East Asia, and its horizontal grid spacing is $12 \mathrm{~km}$ with $601 \times 509$ grid points (Fig. 1). The vertical grid consists of 33 levels. The 6-hourly ERA-Interim data (Dee et al. 2011) with $0.75^{\circ} \times$ $0.75^{\circ}$ horizontal resolution are used to provide the initial and boundary conditions. Since most snowfall events in the YD region occur in January and February, we chose to run the simulation for these two months alone, beginning each run on 1 January of the given year. The simulation was run for each of the 33 years of the 
observational dataset (1982-2014). SST, which acts as the lower boundary forcing in the RCM, is obtained from OISST daily data with a horizontal resolution of $0.25^{\circ} \times 0.25^{\circ}$.

In this study, two sensitivity experiments are conducted to investigate the impact of local SST on snowfall over the YD region. Hereafter, the experiment using observed SST in each year is referred to as the CTL run, and the experiment with East Sea SSTs replaced by the climatological mean is referred to as the CSST run. In the CSST run, SST over the subregion $\left(35^{\circ}-39^{\circ} \mathrm{N}, 128^{\circ}-\right.$ $135^{\circ} \mathrm{E}$ ) is replaced by climatological SST (red box in Fig. 5). The discontinuity of SST in the marginal zone is reduced using a smoothing method. The model configurations are otherwise identical between the two runs.

\section{Relationships between the EAWM, local SST, and snowfall}

Snowfall over the YD region can be affected by the synoptic environment (e.g., pressure patterns and circulation) as well as regional factors (e.g., local SST). In this section, the relationships between the synoptic environment, regional factors, and snowfall are investigated by analyzing the correlations of the interannual variabilities of snowfall over the YD region, the EAWM, and SST over the East Sea.

During the winter season, the synoptic environment over East Asia is closely related to the EAWM. According to Chen et al. (2000), the strong EAWM years are characterized by the robust Siberian high over the Asian continent and the strong Aleutian low to its east. The most prominent surface feature of the strong EAWM is intensified northwesterly winds along the eastern flank of the Siberian high. Jhun and Lee (2004) also showed that a more developed Siberian high and cooler surface temperatures over East Asia are dominant during the strong winter monsoon years, and that most anomalous patterns show opposite behavior in weak EAWM years versus strong EAWM years. In this study, the monsoon variability is described by the EAWM index (EAWMI) defined by Jhun and Lee (2004). This index is based on the $300-\mathrm{hPa}$ meridional wind shear and is known to explain the variability of the winter monsoon in extratropical East Asia reasonably. Interannual variability in snowfall amount over the YD region is negatively correlated with that of the EAWMI with a correlation coefficient of -0.45 (Fig. 2). The EAWMI has peaks in 1984 and 2012, when snowfall anomalies are prominently negative. However, although there are positive anomalies of snowfall in 1989 and 1990, the values of the EAWMI for those two years are relatively low. In contrast to the EAWM, the
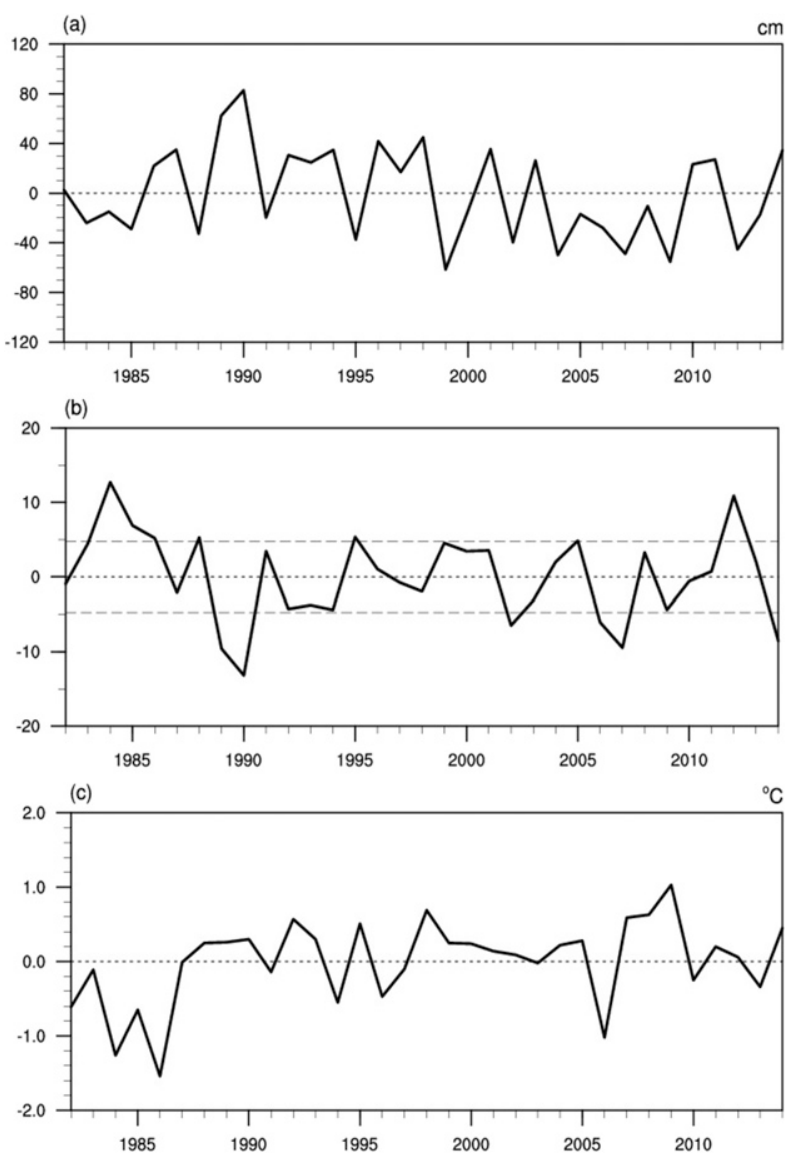

FIG. 2. Time series of (a) snowfall anomaly (cm) over the YD region, (b) the EAWMI, and (c) local SST anomaly $\left({ }^{\circ} \mathrm{C}\right.$ ) over the East Sea $\left(35^{\circ}-39^{\circ} \mathrm{N}, 128^{\circ}-135^{\circ} \mathrm{E}\right)$ in January and February for 33 years (1982-2014). Dashed lines in (b) indicate $\pm 0.8 \sigma$ values of the EAWMI.

interannual variability of local SST anomaly over the East Sea is not significantly correlated with that of snowfall (the correlation coefficient is -0.06). This means that snowfall variability is more affected by the synoptic environment as it relates to the EAWM than by local SST. However, the correlation coefficient between the local SST anomaly over the East Sea and snowfall amount over the YD region significantly increases to 0.42 only for 14 years when the easterly anomaly is dominant over the YD region, indicating that the possibility of heavy snowfall occurrence over the YD region can increase when the synoptic environment, as well as the local SST condition, is favorable.

Since the interannual variability of snowfall over the YD region is closely related to the synoptic environment, we examined the characteristics of the extreme EAWM years using composite analysis. We define seven strong winter monsoon years and six weak winter monsoon years based on the sigma value (i.e., standard 

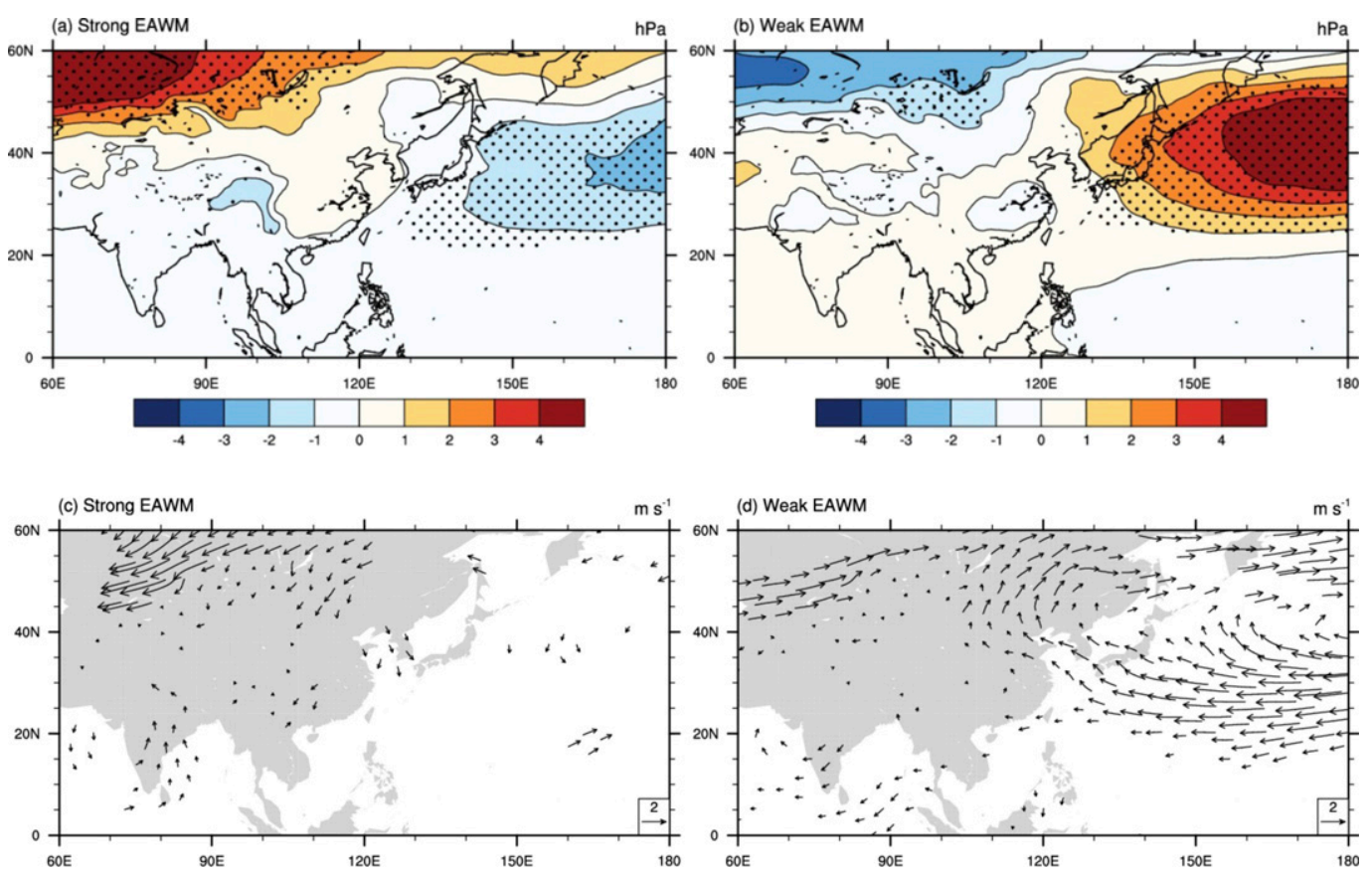

FIG. 3. Composite maps of anomalies of (a),(b) sea level pressure (hPa) and (c),(d) wind vectors at $850 \mathrm{hPa}$ $\left(\mathrm{m} \mathrm{s}^{-1}\right)$ for (left) strong and (right) weak EAWM years. Composite anomalies that are significant at the $90 \%$ confidence level are shown with dots and vectors.

deviation) of the EAWMI (dashed line in Fig. 2b). Seven strong winter monsoon years with sigma greater than +0.8 are identified $(1984,1985,1986,1988,1995$, 2005, and 2012), while six weak winter monsoon years with sigma less than -0.8 are identified $(1989,1990$, 2002, 2006, 2007, and 2014). Interestingly, apart from 1986, snowfall is reduced in the strong EAWM years compared to the 33-yr climatology. For the weak EAWM years, snowfall amount is above the climatological mean only in 1989, 1990, and 2014.

The composite maps of synoptic variables anomalies (i.e., sea level pressure and wind vectors at $850 \mathrm{hPa}$ ) for the strong and weak winter monsoon years are shown in Fig. 3. The strong EAWM years can be characterized by typical pressure patterns in the winter season over East Asia such as the deepened Aleutian low and the developed Siberian high (Fig. 3a). It is noteworthy that the negative anomalies of sea level pressure over the northeastern part of the Korean Peninsula (i.e., Manchuria) prevail because of the deepened Aleutian low, whereas the positive anomalies over central and northern China and the western part of the Korean Peninsula are dominant due to the developed Siberian high. Because of the anomalous pressure distribution, northwesterly anomalies are represented over the Korean Peninsula during the strong EAWM years (Fig. 3c). In contrast, typical pressure patterns in the winter season over East Asia are apparently weakened in the weak
EAWM years. Negative pressure anomalies prevail over the central Asia and Siberia, indicating that the core of the Siberian high is less developed than climatology (Fig. 3b). On the contrary, positive anomalies of sea level pressure are presented over Manchuria and the extratropical western North Pacific due to the weakened Aleutian low, indicating that the Siberian high can more frequently surge eastward. In the composite map of lower-level wind anomalies, similarly, the enhanced easterly near the eastern coastal region of South Korea, which is the most necessary condition for snowfall, is dominant during the weak EAWM years (Fig. 3d).

To investigate the temporal evolution of anomalies of sea level pressure over Manchuria and low-level wind over the YD region and the East Sea, we analyzed the time-longitude graphs averaged for the extreme EAWM years. In the case of snowfall over the YD region, the eastward surge or expansion of the Siberian high to Manchuria is significantly important because it induces easterlies over the East Sea, which are the essential condition for snowfall over the YD region. In other words, heavy snowfall over the YD region cannot occur if the Siberian high does not expand to Manchuria. In the time-longitude graph for strong EAWM years, negative anomalies of sea level pressure are dominant over Manchuria during January and February (Fig. 4a). This indicates that it is difficult for the Siberian high to surge to Manchuria due to the deepened Aleutian low. 
a) Sea level pressure

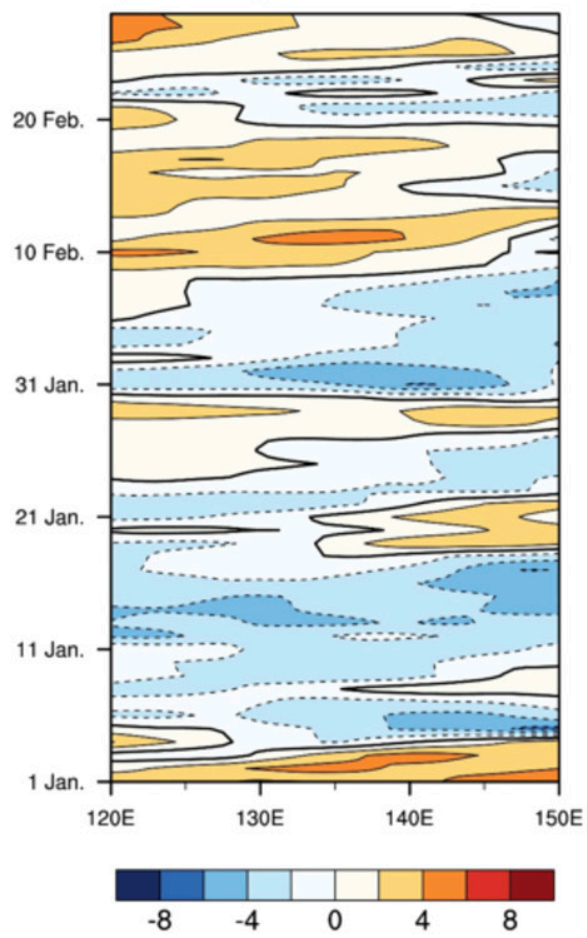

c) Sea level pressure

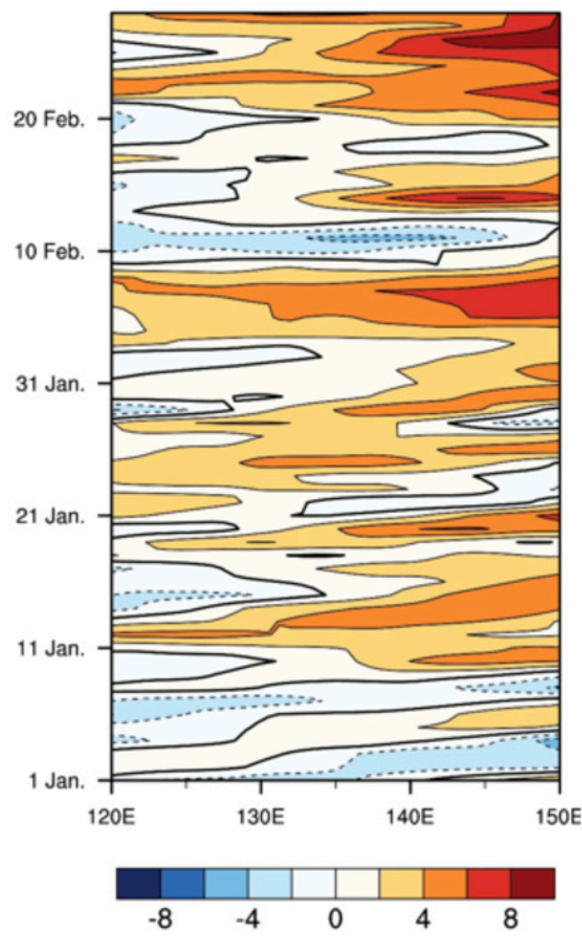

b) $850 \mathrm{hPa}$ Zonal wind

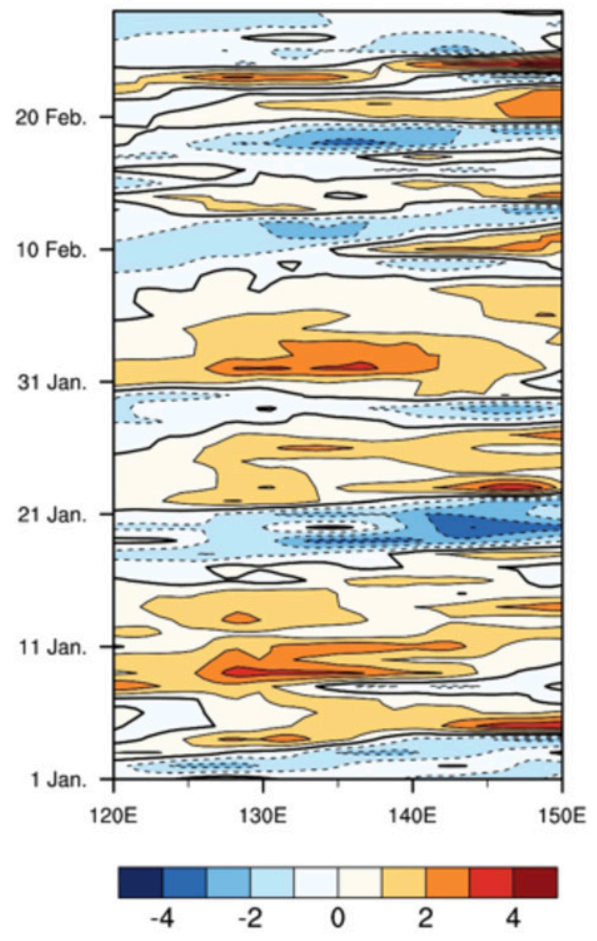

d) $850 \mathrm{hPa}$ Zonal wind

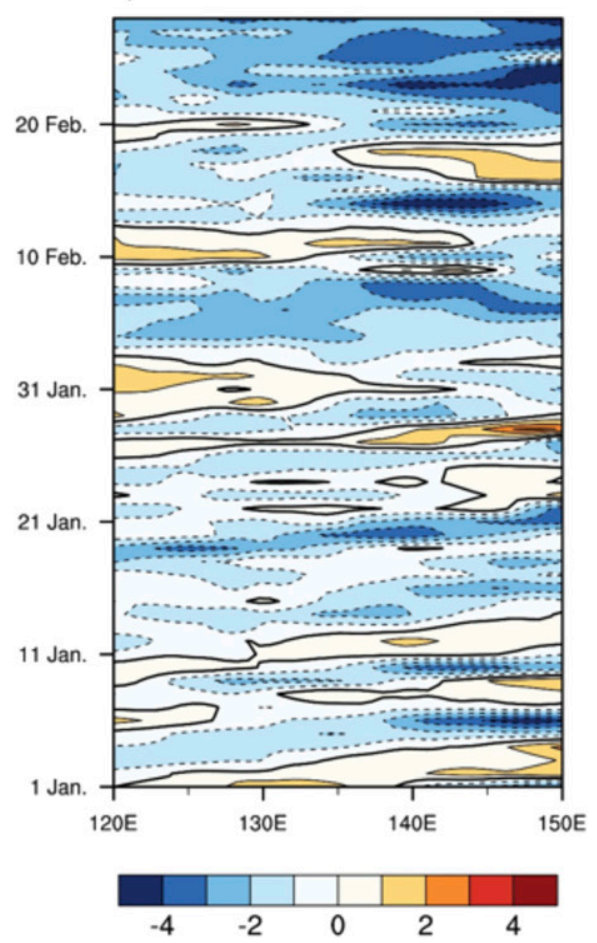

FIG. 4. Time-longitude graphs of (a),(c) sea level pressure (hPa) and (b),(d) zonal wind at $850 \mathrm{hPa}$ $\left(\mathrm{m} \mathrm{s}^{-1}\right)$ anomalies averaged for (top) strong and (bottom) weak EAWM years. Meridional mean areas are $40^{\circ}-50^{\circ} \mathrm{N}$ for sea level pressure and $30^{\circ}-40^{\circ} \mathrm{N}$ for zonal wind. 
(a) Strong EAWM

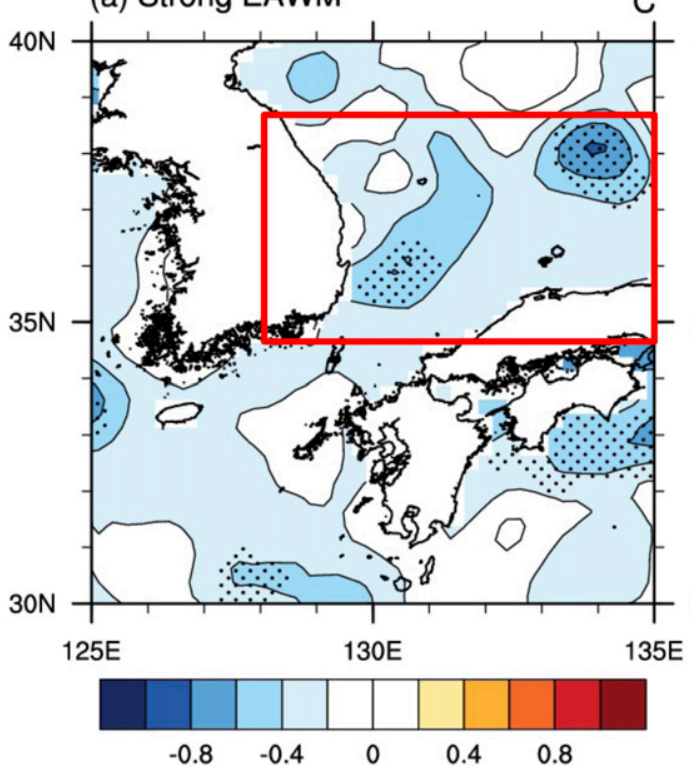

(b) Weak EAWM

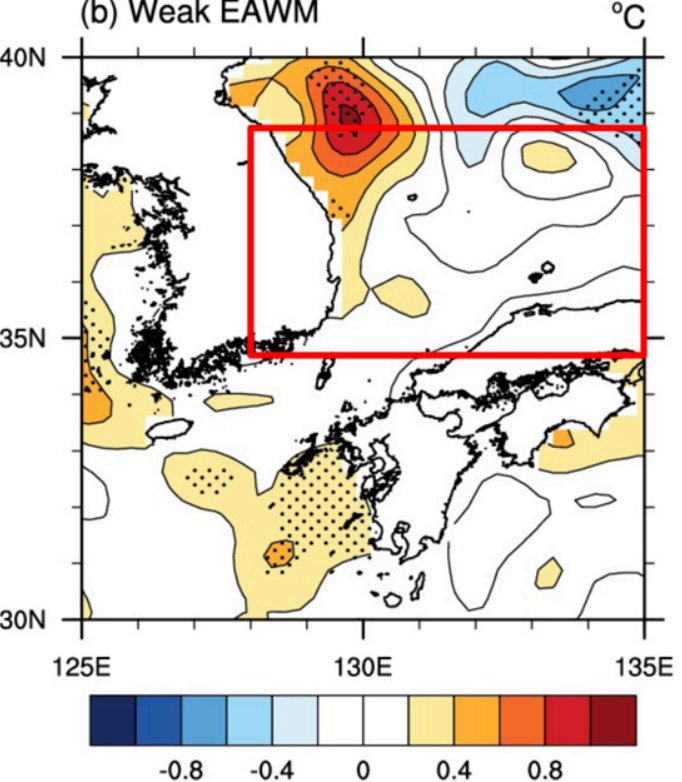

FIG. 5. Composite maps of anomalies of sea surface temperature $\left({ }^{\circ} \mathrm{C}\right)$ near the Korean Peninsula for (a) strong and (b) weak EAWM years. Composite anomalies that are significant at the $90 \%$ confidence level are shown with dots. The red box indicates the subregion $\left(35^{\circ}-39^{\circ} \mathrm{N}, 128^{\circ}-135^{\circ} \mathrm{E}\right)$ for the CSST run.

Therefore, westerly anomalies over the YD region prevail, which are not favorable conditions for snowfall over the YD region. In contrast, positive anomalies of sea level pressure over Manchuria implying the eastward surge of the Siberian high are enhanced during January and February in the weak EAWM years, and the associated easterly anomalies over the YD region are robust. Therefore, the synoptic conditions for snowfall over the YD region can be possibly more favorable in the weak EAWM years compared with the strong EAWM years.

In addition to the synoptic environment, local SST over the East Sea can play a substantial role in influencing snowfall over the YD region, particularly for the weak EAWM years. The composite maps of local SST anomalies for the extreme winter monsoon years are shown in Fig. 5. In the strong EAWM years, local SST tends to be anomalously colder than climatology (Fig. 5a), whereas it tends to be warmer in the weak EAWM years, in particular offshore near the YD region (Fig. 5b). A warm (cold) SST anomaly in weak (strong) EAWM years can be associated with reduced (enhanced) cold advection and less (more) latent heat flux at the surface. As indicated by Jhun and Lee (2004), SST around China, the Korean Peninsula, and Japan can be affected by atmospheric advection induced by the EAWM. In the strong EAWM years, cold SST anomaly can be induced due to the enhanced cold advection from higher latitudes, while warm SST anomaly may be dominant in the weak EAWM years because of the decreased cold advection. In addition, less latent heat flux can be related to warm SST anomaly in the weak EAWM years as indicated by Chen et al. (2015). Although the latent heat flux averaged for winter monsoon period is less than the climatology, warmer SST anomaly in the weak EAWM years can provide easterly into the YD region with sufficient heat and moisture to cause abnormally heavy snowfall (Cha et al. 2011b; Jung et al. 2012). Therefore, the probability that local SST as well as synoptic conditions are favorable for the snowfall over the YD region is higher in the weak EAWM years than the strong EAWM years.

\section{Impacts of the synoptic environment and local SST on snowfall over the YD region}

\section{a. Observational analysis}

As indicated in the previous section, the interannual variability of snowfall over the YD region is closely related to the EAWM. The SST conditions and the synoptic environment are more conducive to snowfall over the YD region in the weak EAWM years than in the strong EAWM years. To elucidate the differences in synoptic conditions between the strong and weak EAWM years, we analyze the temporal evolutions of sea level pressure over Manchuria (Fig. 6) and low-level zonal wind over the YD region and the East Sea for each year (Fig. 7). As previously noted, the eastward 

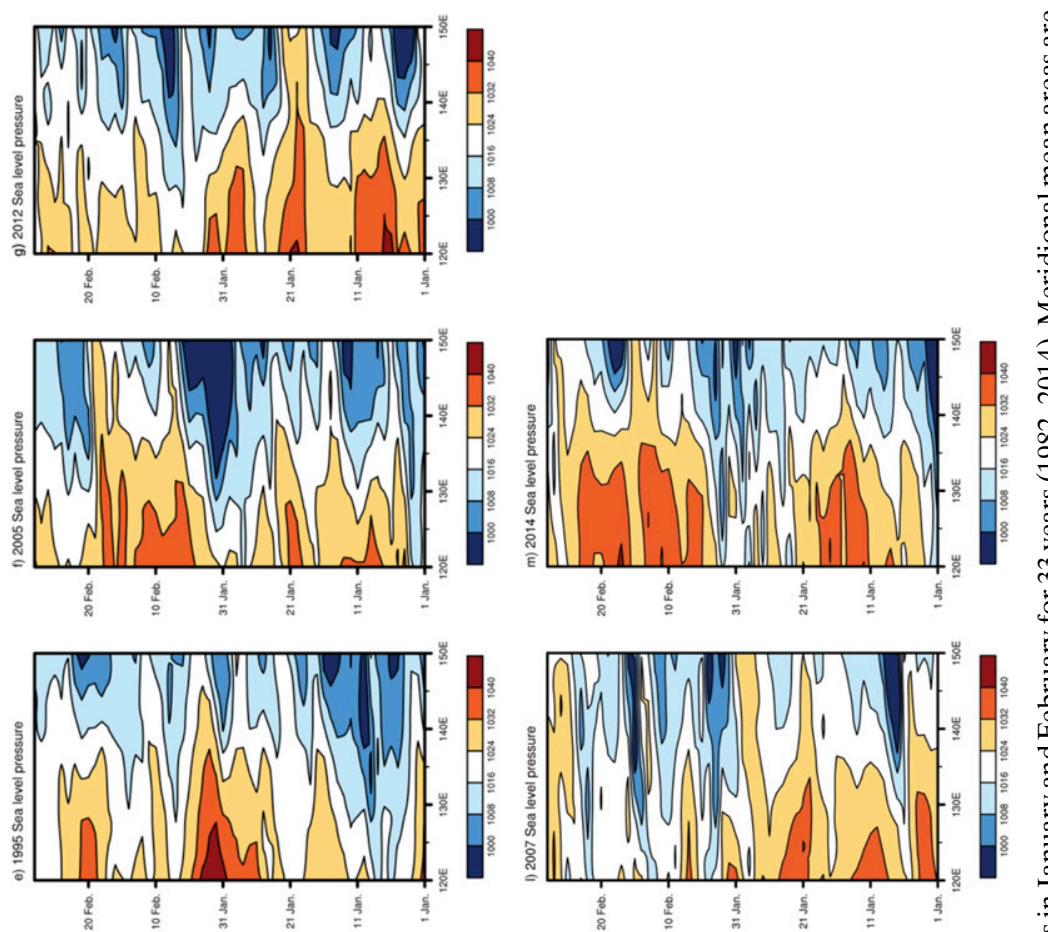

要
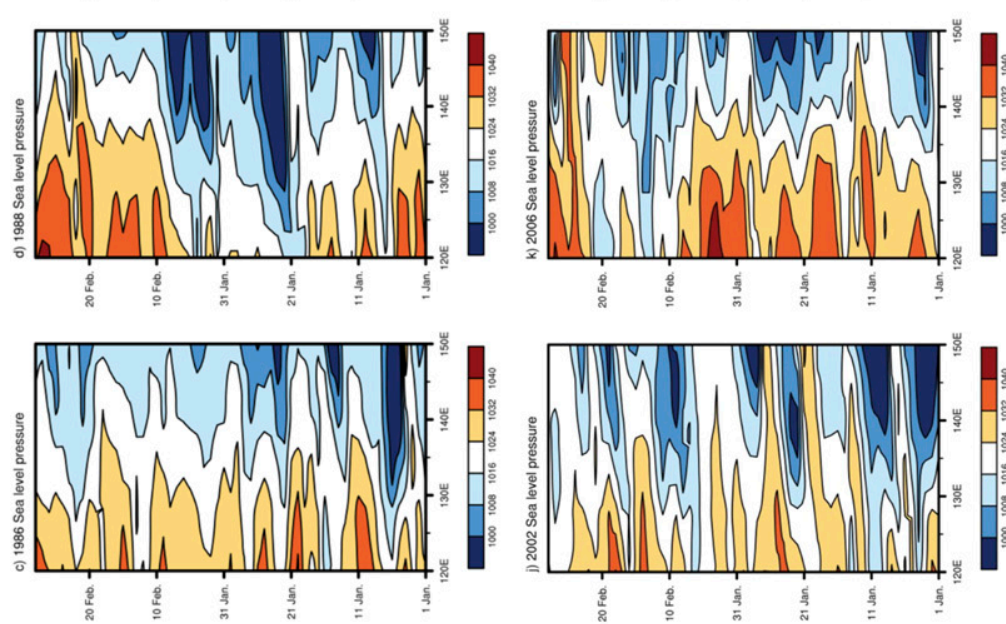

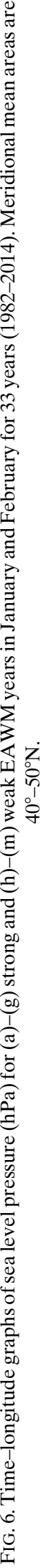
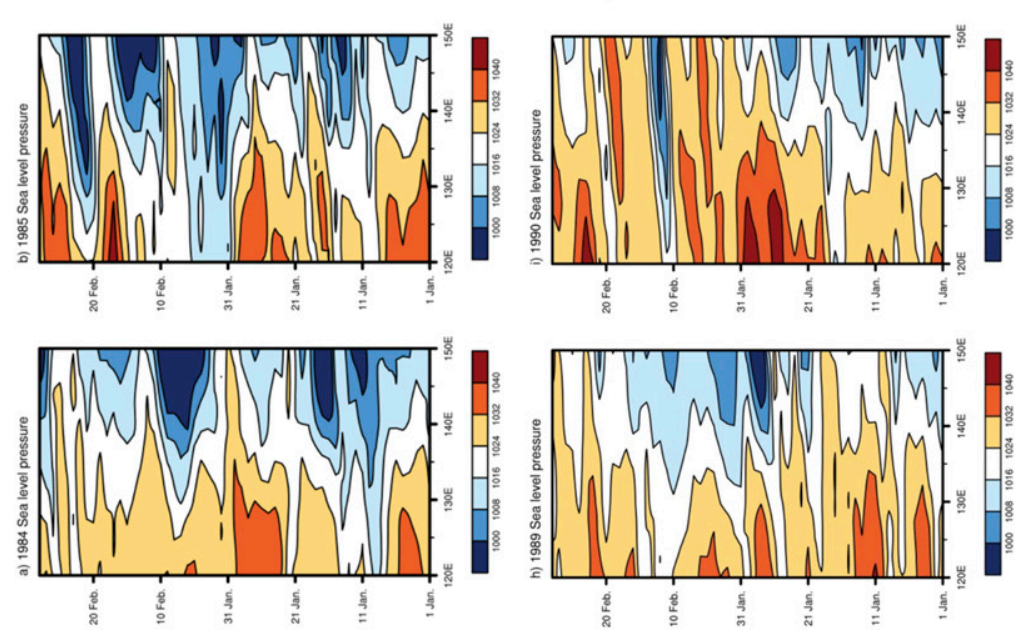

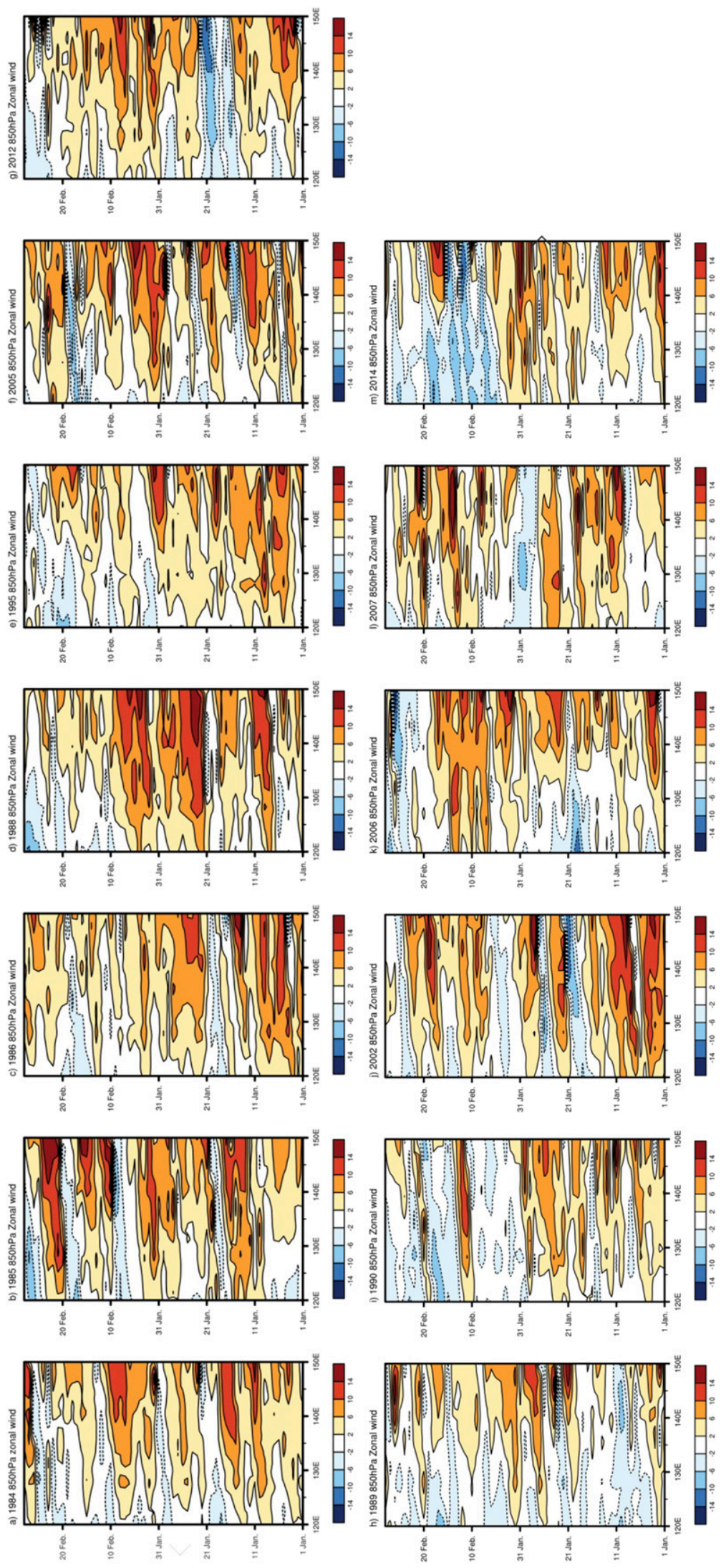
TABLE 1. Total snowfall amount $(\mathrm{cm})$, snowfall days, and the maximum amount of daily snowfall for each weak EAWM year over the YD region (averaged value of four stations).

\begin{tabular}{cccccc}
\hline \hline & $\begin{array}{c}\text { Total snowfall amount } \\
(\mathrm{cm})\end{array}$ & $\begin{array}{c}\text { Snowfall days } \\
(>0 \mathrm{~cm})\end{array}$ & $\begin{array}{c}\text { Snowfall days } \\
(\geq 5 \mathrm{~cm})\end{array}$ & $\begin{array}{c}\text { Snowfall days } \\
(\geq 15 \mathrm{~cm})\end{array}$ & $\begin{array}{c}\text { Maximum amount of daily snowfall } \\
(\mathrm{cm})\end{array}$ \\
\hline 1989 & 126.7 & 26 & 7 & 3 & 22.6 \\
1990 & 147.2 & 24 & 5 & 3 & 41 \\
2002 & 24.8 & 19 & 2 & 0 & 8.2 \\
2006 & 36.6 & 18 & 3 & 0 & 7.6 \\
2007 & 15.5 & 13 & 0 & 0 & 3 \\
2014 & 98.8 & 18 & 6 & 2 & 18.9 \\
\hline
\end{tabular}

expansion of the Siberian high to the northeastern part of the Korean Peninsula (i.e., Manchuria) is the most common pressure pattern leading to the occurrence of snowfall over the YD region. During January and February of strong EAWM years, it is generally true that Manchuria around $130^{\circ}-140^{\circ} \mathrm{E}$ is more frequently affected by the Aleutian low rather than the Siberian high (Figs. 6a-g). This means that the possibility of the expansion of the Siberian high to Manchuria is relatively low due to the enhanced Aleutian low in the strong EAWM years. Also, the associated low-level westerly wind prevails over the YD region and the East Sea (Figs. 7a-g). Therefore, snowfall amounts over the YD region in the strong EAWM years tend to be less than in other years (see Fig. 2).

In the weak EAWM years, the temporal evolution patterns of sea level pressure and low-level wind are generally opposite to those in the strong EAWM years. However, the total accumulated amount of snowfall is not consistent among the weak EAWM years, being much larger in 1989, 1990, and 2014 than in 2002, 2006, and 2007 (Table 1). During the latter three years, total snowfall amounts were below $50 \mathrm{~cm}$. Indeed, in 2007 there was no day when the daily accumulated amount of snowfall was greater than $5 \mathrm{~cm}$, and the maximum daily snowfall accumulation was the smallest among the six weak EAWM years. Although the core of the Siberian high is developed around the central Siberian region during all weak EAWM years, the associated circulation and in particular the magnitude of the surge differ. During the large snowfall years (i.e., 1989, 1990, and 2014), the Siberian high has more frequently expanded into the northeastern part of the Korean Peninsula (around $130^{\circ} \mathrm{E}$ ) (Figs. 6h,i,m) and an easterly low-level wind prevails over the East Sea (Figs. 7h,i,m). The eastward surge of the Siberian high induces an easterly wind over the East Sea, which transports heat and moisture from the relatively warm ocean to the YD region. This can lead to increased atmospheric instability, resulting in convection that then induces heavy snowfall. In contrast, two of the years with lower snowfall amounts (i.e., 2002 and 2007) are characterized by a less pronounced surge of the Siberian high (Figs. 6j,1) and the domination of westerly wind at $850 \mathrm{hPa}$ over the East Sea (Figs. 7j,1). Easterly inflow to the YD region, which is crucial for the occurrence of snowfall, is significantly weak in these two years. It is noteworthy that the total accumulated amount of snowfall in $2006(36.6 \mathrm{~cm})$ is smaller than the climatological mean, despite the synoptic conditions being somewhat favorable for snowfall over the YD region (Figs. 6k and 7k).

The presence of a warm SST anomaly near the YD region during all weak EAWM years except for 2006 (Fig. 8) indicates that the thermal condition of the ocean is generally favorable during weak monsoon years. Despite favorable oceanic conditions during five of the weak monsoon years, anomalously large snowfalls occurred only in 1989, 1990, and 2014, when the conditions for the synoptic environment (i.e., an expanded Siberian high and easterly wind) were also satisfied. Notably, a cold SST anomaly in 2006 led to little snowfall despite the favorable synoptic environment. Likewise, snowfall amounts in 2002 and 2007 are anomalously small due to the unfavorable synoptic environment despite warm SST anomalies. Zonal wind over the YD region and local SST anomalies over the East Sea for the weak EAWM years are presented in Table 2. The favorable synoptic condition for snowfall over the YD region is an easterly anomaly related to the surge of the Siberian high, and the favorable oceanic condition is a warm local SST anomaly. As mentioned previously, snowfall amounts are large in 1989, 1990, and 2014 because both the synoptic environment and oceanic conditions are favorable. However, snowfall amounts are relatively small in other years when only one condition is satisfied. Thus, snowfall over the YD region in weak EAWM years tends to be affected by the combined effects of the synoptic environment and local SST.

To clarify that synoptic conditions and SST anomaly in the weak EAWM years are possibly more favorable for snowfall over the YD region, we analyze the time 
(a) 1989

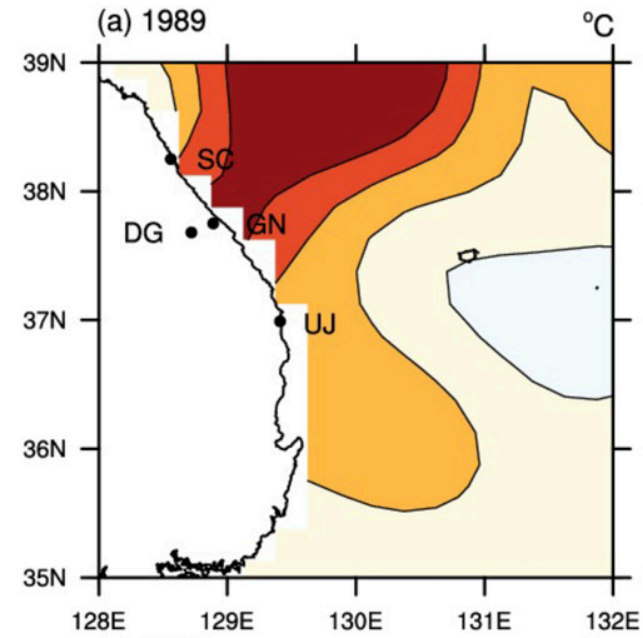

(b) 1990

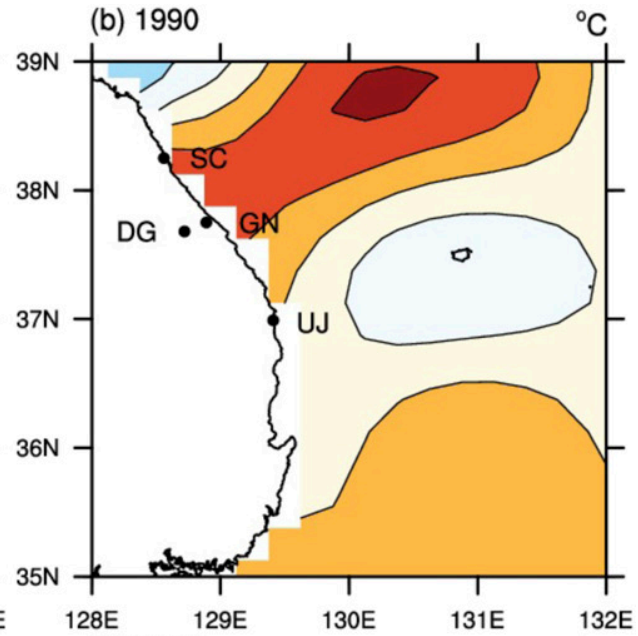

(c) 2002

(d) 2006

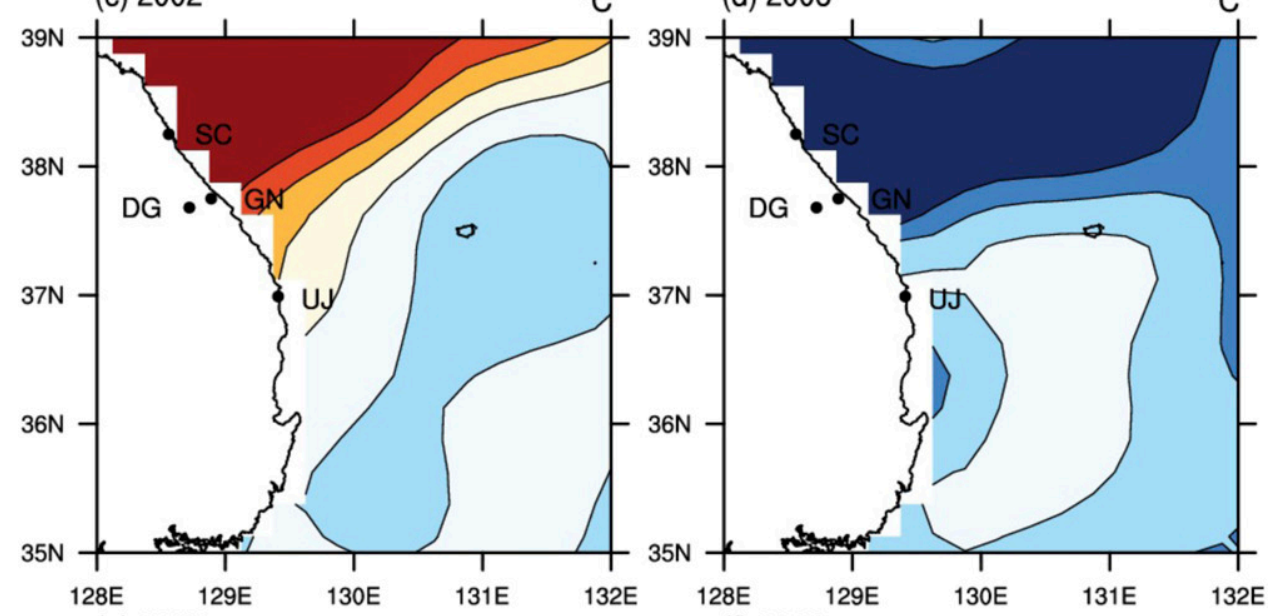

$32 \mathrm{E}$

(e) 2007

${ }^{\circ} \mathrm{C} \quad$ (f) 2014

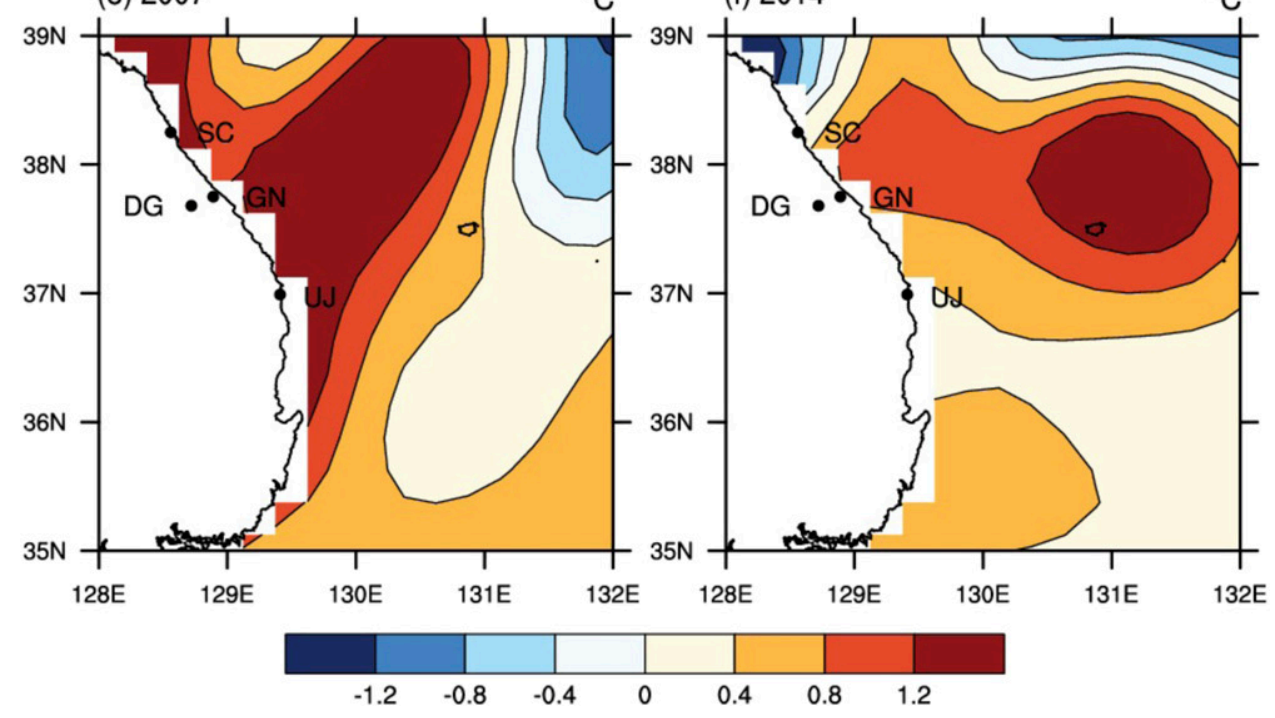

FIG. 8. Two-month (January and February)-averaged sea surface temperature anomaly $\left({ }^{\circ} \mathrm{C}\right)$ for each weak EAWM year. 
TABLE 2. Synoptic environment and local SST anomaly for each weak EAWM years. Boldface values indicate favorable conditions for snowfall amount over the YD region.

\begin{tabular}{ccc}
\hline \hline & $\begin{array}{c}\text { Zonal wind anomaly }\left(\mathrm{m} \mathrm{s}^{-1}\right) \\
\text { at } 850 \mathrm{hPa} \text { over the } \mathrm{YD} \\
\text { region }\left(36.5^{\circ}-38.5^{\circ} \mathrm{N},\right. \\
\left.128.5^{\circ}-130^{\circ} \mathrm{E}\right)\end{array}$ & $\begin{array}{c}\text { SST anomaly }\left({ }^{\circ} \mathrm{C}\right) \text { over } \\
\text { the East Sea }\left(35^{\circ}-39^{\circ} \mathrm{N},\right. \\
\left.128^{\circ}-135^{\circ} \mathrm{E}\right)\end{array}$ \\
\hline 1989 & $\mathbf{- 2 . 6 3}$ & $\mathbf{+ 0 . 2 6}$ \\
1990 & $\mathbf{- 1 . 4 8}$ & $\mathbf{+ 0 . 3 0}$ \\
2002 & +0.54 & +0.09 \\
2006 & $\mathbf{- 0 . 2 3}$ & -1.02 \\
2007 & +0.51 & $\mathbf{+ 0 . 5 9}$ \\
2014 & $\mathbf{- 1 . 2 0}$ & $\mathbf{+ 0 . 4 5}$ \\
\hline
\end{tabular}

series of snowfall amount over the YD region and latent heat flux anomaly over the East Sea, and 5-day mean pressure, low-level circulation, surface latent heat flux, and SST anomaly around the Korean Peninsula during early and mid-February in 2014 among the weak EAWM years. During this period heavy snowfall consecutively occurred over the YD region (Fig. 9a). In period 1 (Fig. 9b), the eastern boundary of the Siberian high is located in northern China, not expanding to Manchuria, and northwesterly wind prevails over the entire Korean Peninsula. Therefore snowfall events hardly occur over the YD region despite a slightly warm SST anomaly over the East Sea. In period 2 (Fig. 9c), the Siberian high prominently expands to Manchuria, and an easterly from the East Sea to the YD region induced by the anticyclonic circulation appears. In addition, a warm SST anomaly over the East Sea can increase low-level moisture by enhancing latent heat flux or the Clausius-Clapeyron relationship as mentioned by Takahashi et al. (2013). Then moist air is transported by the easterly and converges over the YD region due to high mountain ranges. Therefore, severe snowfall events occur over the YD region during this period. Since the synoptic conditions and SST anomaly continue in period 3 (Fig. 9d), heavy snowfall events occur again. It is notable that the correlation coefficient between latent heat flux anomaly over the East Sea and snowfall amount over the YD region is 0.38 in Fig. 9a, which clarifies that warm SST during the weak EAWM years could lead to the heavy snowfall over the YD region by increasing the latent heat flux. Despite the weakened easterly, relatively light snowfall events occur in period 4 (Fig. 9e) because the warm SST anomaly over the East Sea is further enhanced. This delineates that the possibility of the synoptic conditions and SST anomaly being more satisfactory for heavy snowfall over the YD region is overall higher in the weak EAWM years than the strong EAWM years, although they have large intraseasonal variability during the monsoon period.

\section{b. SST sensitivity test results}

To investigate the impacts of the synoptic environment and local SST on snowfall over the YD region in detail, a sensitivity experiment is conducted using an RCM based on the WRF Model. Because it is much more difficult to modify the synoptic environment in a numerical experiment than SST, we chose to test only the impact of changes in SSTs. This was done by comparing a model run using historical SSTs (CTL run) to a model run with SSTs set to the climatological mean (CSST run).

The performance of the CTL run of the WRF-based RCM is evaluated against observations acquired from four stations (SC, GN, DG, and $\mathrm{UJ}$ ) in the YD region (Fig. 10). Simulated snowfall is bilinearly interpolated to the location of each station, and the snow ratio equation from Byun et al. (2008) is applied to convert the liquid phase of precipitation to the solid phase of snowfall. The amount of snowfall for each year is calculated by averaging total snowfall accumulations for January and February at the four stations.

The temporal correlation coefficient and bias between simulated and observed snowfall amounts are 0.56 and 2.29 , respectively. The large correlation coefficient and positive bias mean that while the RCM reproduces the interannual variability of snowfall over the YD region reasonably well, it tends to overestimate snowfall. Furthermore, the correlation coefficient between the observed EAWMI and simulated snowfall amount over the YD region is -0.36 . Therefore, the RCM realistically captures the impact of the EAWM on the interannual variability of snowfall over the YD region. Since heavy snowfall is much more likely in the weak EAWM years, we also evaluate the model performance only for the weak EAWM years (Table 3). Despite slightly overestimating snowfall amounts, the CTL run captures the interannual differences between the six weak EAWM years. In particular, the CTL run succeeds in simulating more (less) snowfall amounts in 1989, 1990, and 2014 (2002, 2006, and 2007). Therefore, the WRF-based RCM is able to simulate both the interannual variability and total seasonal amount of snowfall over the YD region and can be used to test sensitivity to local SST.

To examine the impact of local SST anomalies on snowfall over the YD region, total snowfall amount is compared between CTL and CSST runs for the weak EAWM years, during which local SST has a significant effect on snowfall, as noted in section 3 (Fig. 11). The difference between the two runs is particularly large along the eastern coastal region of the Korean Peninsula and over the YD region in particular. In the weak 
(a) Snowfall amount $(\mathrm{cm})$ and latent heat flux anomaly $\left(\mathrm{W} \cdot \mathrm{m}^{-2}\right)$

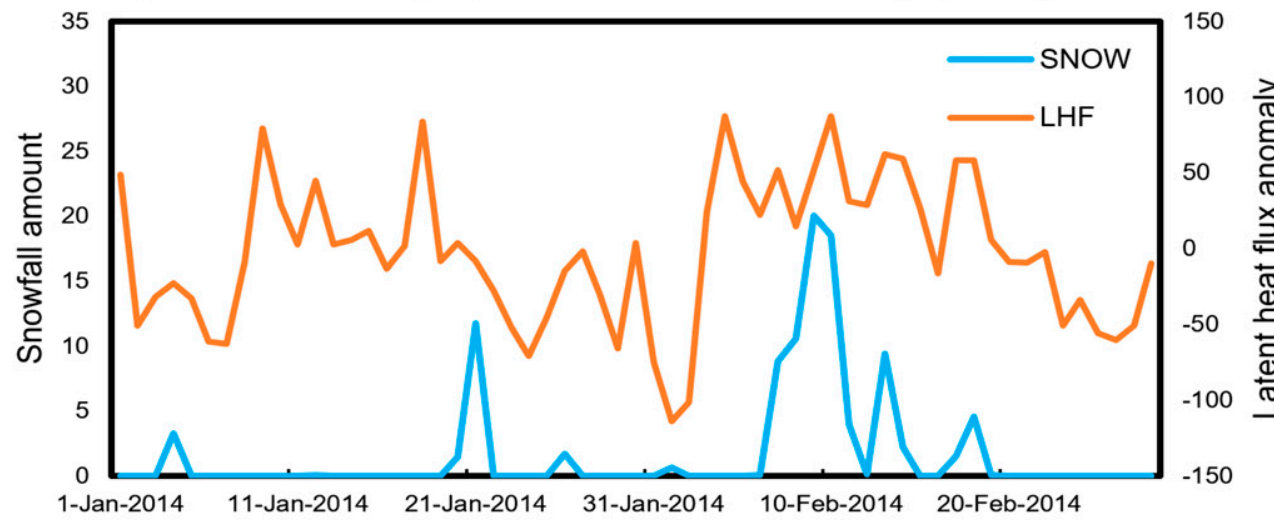

(b) Period 1 (Feb. 1 - Feb. 5)

(c) Period 2 (Feb. 6 - Feb. 10)
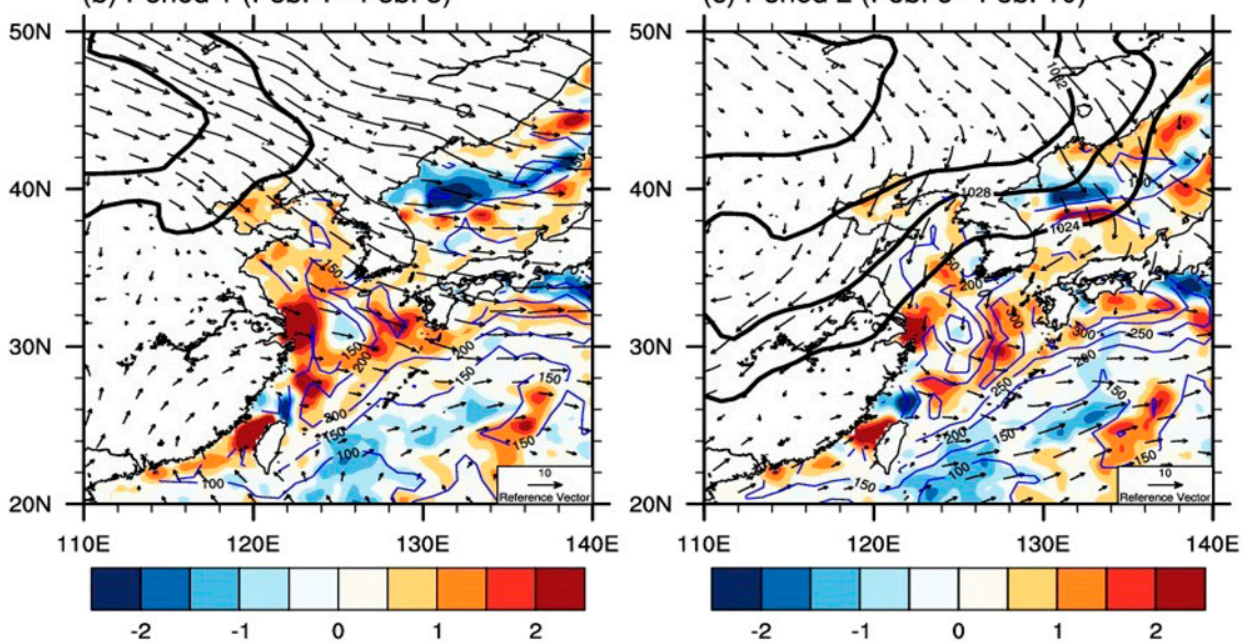

(d) Period 3 (Feb. 11 - Feb. 15)

(e) Period 4 (Feb. 16 - Feb. 20)
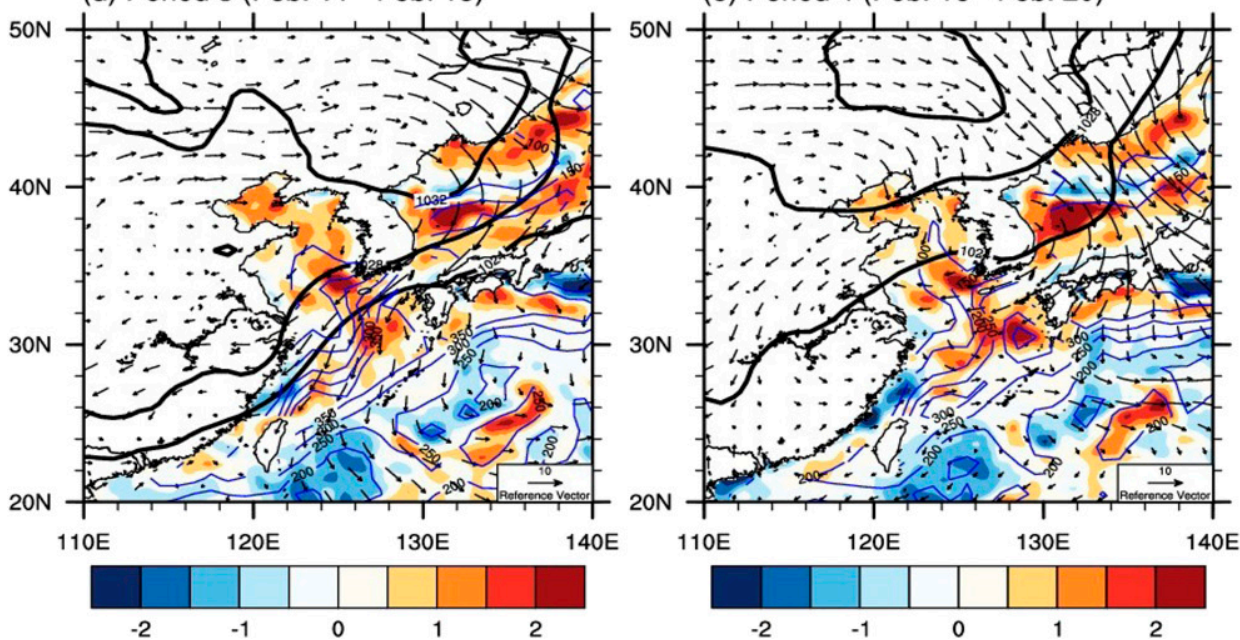

FIG. 9. (a) Time series of observed snowfall amount averaged for four stations in the YD region with latent heat flux anomaly over the East Sea $\left(35^{\circ}-39^{\circ} \mathrm{N}, 128^{\circ}-135^{\circ} \mathrm{E}\right)$, and (b)-(e) 5-day mean synoptic fields of sea level pressure (black thick contours; $\mathrm{hPa}$ ), 850-hPa wind (vectors; $\mathrm{m} \mathrm{s}^{-1}$ ), SST anomaly (shading; $\mathrm{K}$ ), and surface latent heat flux (blue contours; $\mathrm{W} \mathrm{m}^{-2}$ ) in 2014. The SST anomaly is calculated from OISST, the latent heat flux is obtained from OAFlux, and others are from ERA-Interim. 


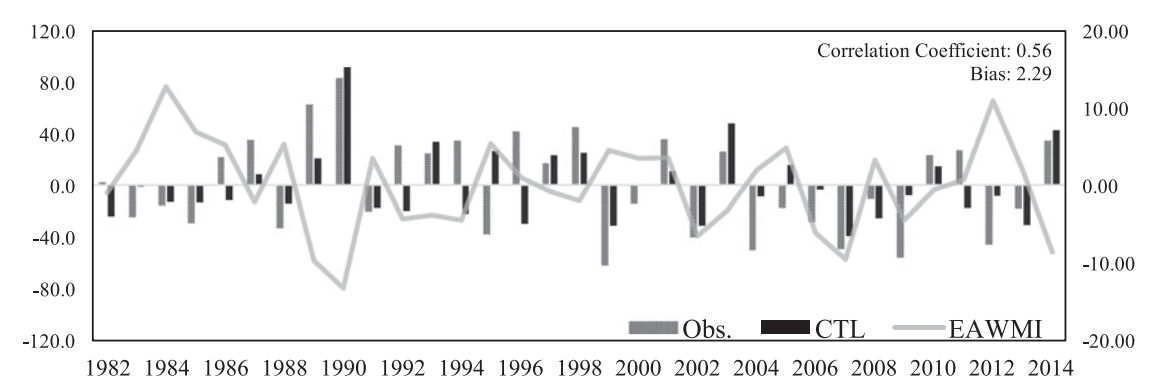

FIG. 10. Anomalies of total snowfall amount $(\mathrm{cm})$ of each year over the YD region acquired from observations (dashed bar) and the RCM (black bar) and a time series of the EAWMI (solid line) in January and February.

EAWM years, the difference between the model runs in terms of snowfall amount over the YD region is strongly related to the local SST anomaly in the East Sea. Warm SST anomalies in the East Sea are associated with greater snowfall over the YD region in 1989, 1990, 2002, and 2014, whereas the cold SST anomaly in 2006 is associated with reduced snowfall. The difference in snowfall amount between the CTL and CSST runs is largest in 1990, for which it is more than $90 \mathrm{~cm}$. Warm SST anomalies increase snowfall by enhancing moisture and heat fluxes (Kang and Ahn 2008; Cha et al. 2011b). Table 3 presents a quantitative comparison of total snowfall amount and relative rate of change between the CTL and CSST runs. In the CTL run, warm SST anomalies in the East Sea are associated with larger snowfall amounts (i.e., 1989, 1990, 2002, and 2014) and cool SST anomalies are associated with less snowfall (i.e., 2006). Interestingly, in 2006, the cool SST anomaly in the CTL run is associated with $41.7 \%$ less snowfall than the CSST run despite the synoptic environment being favorable. This result supports the idea that both the SST anomalies and the synoptic environment are important in determining snowfall amounts over the YD region. Furthermore, despite the warm SST anomaly in 2007, the CTL and CSST runs simulate similar snowfall because the synoptic environment is unfavorable.

To identify the thermodynamic effect of local SST anomalies on snowfall amount, the moisture convergence and moisture flux at $850 \mathrm{hPa}$ in the CTL and CSST runs are compared (Fig. 12). In the years with warm SST anomalies (i.e., 1989, 1990, 2002, 2007, and 2014), the CTL run simulates more latent heat flux from the ocean to the low-level atmosphere than the CSST run, whereas the reverse is true in years with cold SST anomalies (i.e., 2006) (not shown). This is because warm SST anomalies increase the vertical moisture gradient between the ocean surface and low-level atmosphere in wintertime. Although SST anomalies can also change atmospheric circulation, the difference in circulation between two runs is not significant due to the limited size of subregion with climatological SST in CSST run. Therefore, SST conditions thermodynamically modify atmospheric moisture amount by changing latent heat flux at the sea surface, which is the main source of energy for the formation of snowfall over the YD region (Jung et al. 2012). Also, it can change low-level moisture amount according to the Clausius-Clapeyron relationship as indicated by Takahashi et al. (2013). In addition, an easterly anomaly dominates over the YD region in 1989, 1990, 2006, and 2014, whereas a westerly anomaly is prominent in 2002 and 2007 (see Table 2). Moisture convergence is determined by the combined effects of local SST and the synoptic environment. In the years with warm SST anomalies as well as easterly anomalies (e.g., 1989, 1990, and 2014), the CTL run simulates enhanced moisture convergence over the YD region compared to the CSST run. This means that the increased low-level moisture induced by the warm SST anomaly is transported westward by the easterly wind before converging over the YD region due to the topographical blocking of the Taebaek Mountains. However, in 2006, an easterly anomaly is associated with a cold SST anomaly, and the CTL run simulates decreased moisture flux from the East Sea to the YD region due to reduced latent heat over the ocean, with the result that moisture divergence is enhanced over

TABLE 3. Total snowfall amount $(\mathrm{cm})$ of observations (obs) and each experiment and relative change in snowfall of CTL from CSST run for each weak EAWM years The values of each snowfall amount are the average of four stations in the YD region.

\begin{tabular}{lcccc}
\hline \hline & Obs $(\mathrm{cm})$ & CTL $(\mathrm{cm})$ & CSST $(\mathrm{cm})$ & Relative change $(\%)$ \\
\hline 1989 & 126.7 & 87.4 & 49.9 & +75.2 \\
1990 & 147.2 & 158.5 & 51.4 & +208.4 \\
2002 & 24.8 & 32.2 & 22.4 & +43.8 \\
2006 & 36.6 & 63.5 & 108.9 & -41.7 \\
2007 & 15.5 & 27.8 & 28.2 & -1.4 \\
2014 & 98.8 & 109.5 & 91.2 & +20.0 \\
\hline
\end{tabular}


(a) 1989

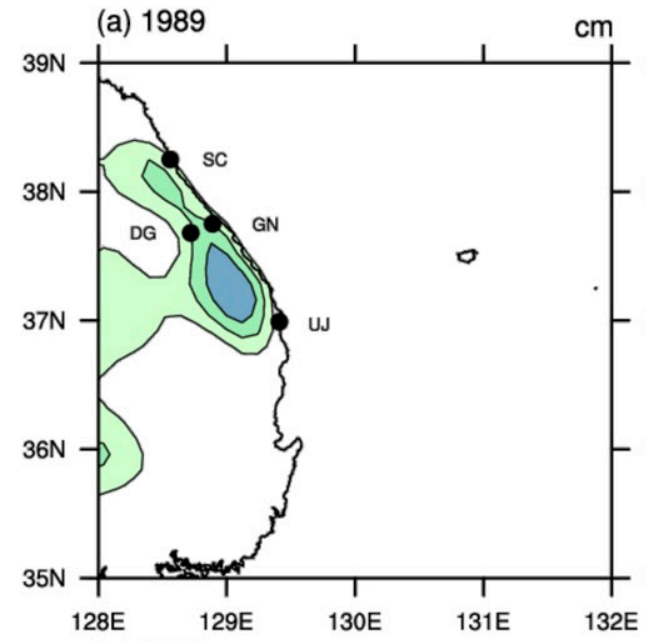

(b) 1990

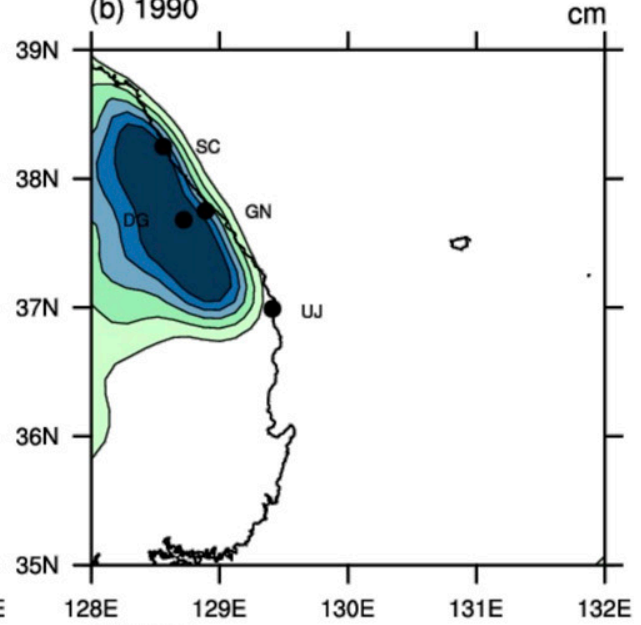

(c) 2002

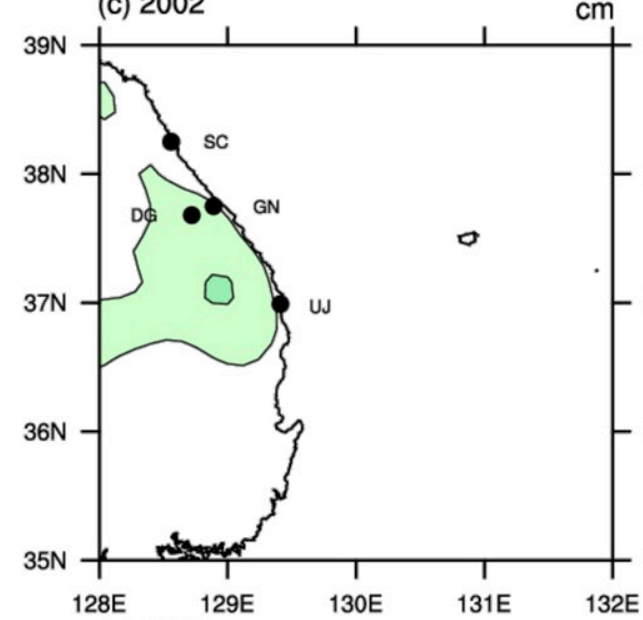

(d) 2006

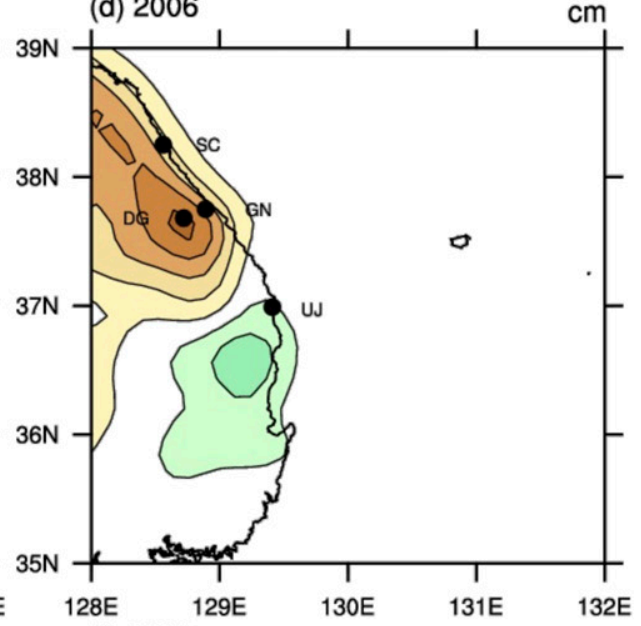

(e) 2007

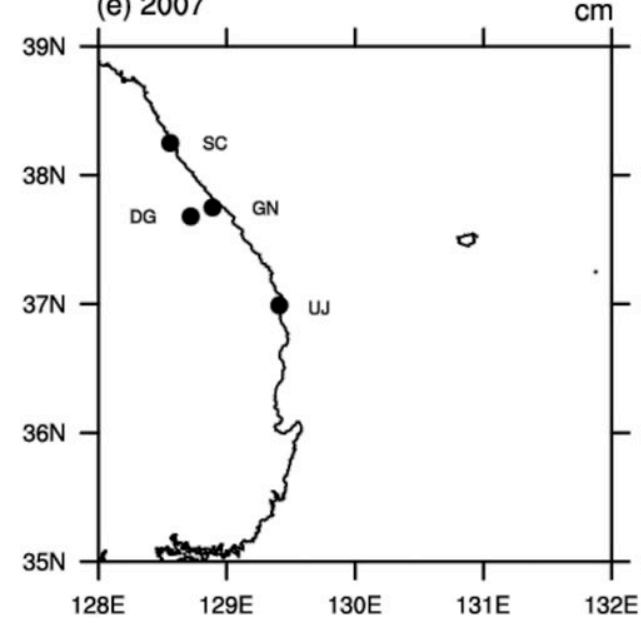

(f) 2014

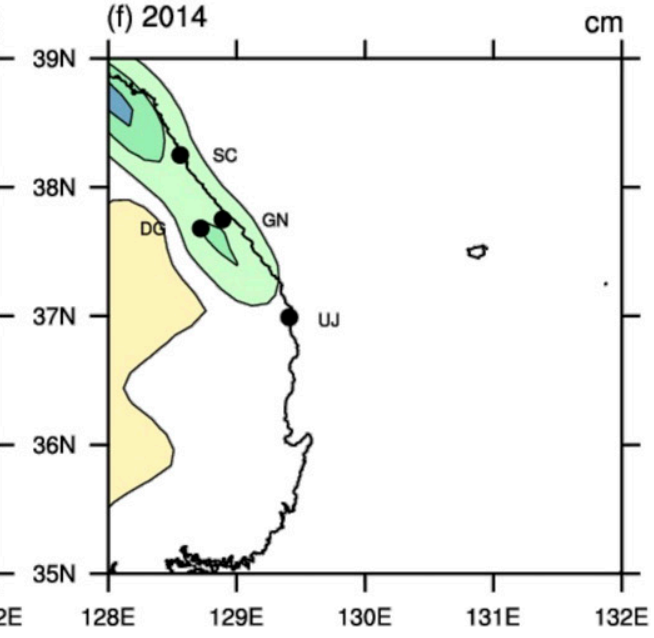

$\begin{array}{llllllllll}-90 & -70 & -50 & -40 & -30 & 30 & 40 & 50 & 70 & 90\end{array}$

FIG. 11. Difference in 2-month (January and February) mean total accumulated snowfall $(\mathrm{cm})$ between CTL and CSST runs for each weak EAWM years (CTL minus CSST). 
(a) 1989

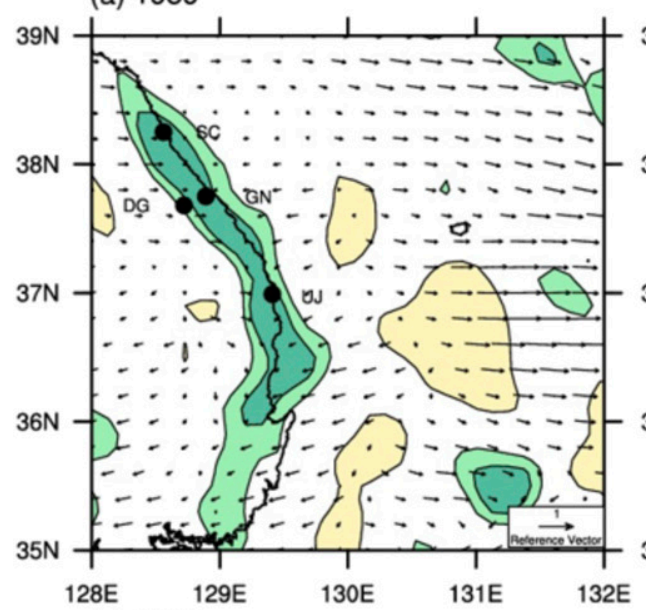

(c) 2002

(b) 1990

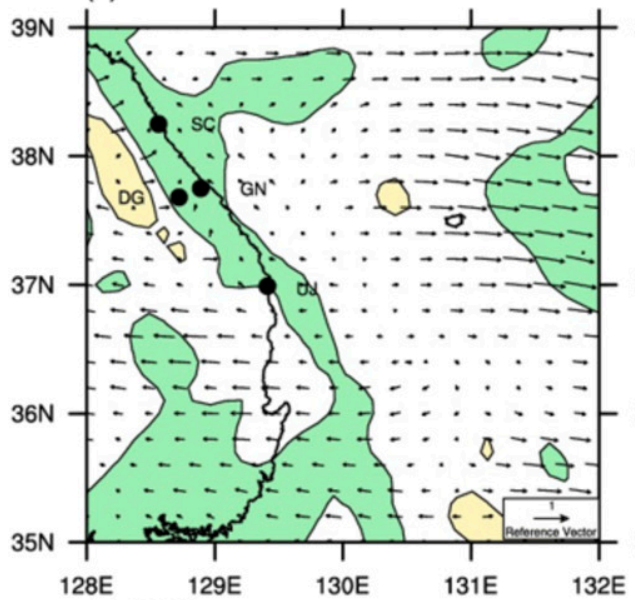

(e) 2007

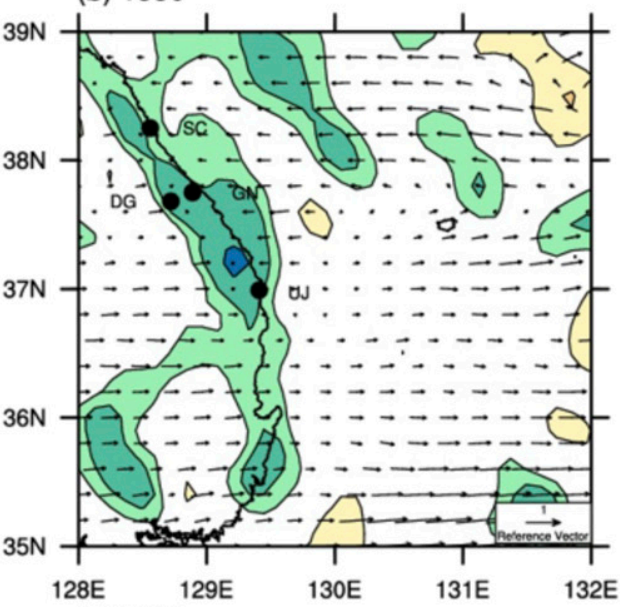

(d) 2006

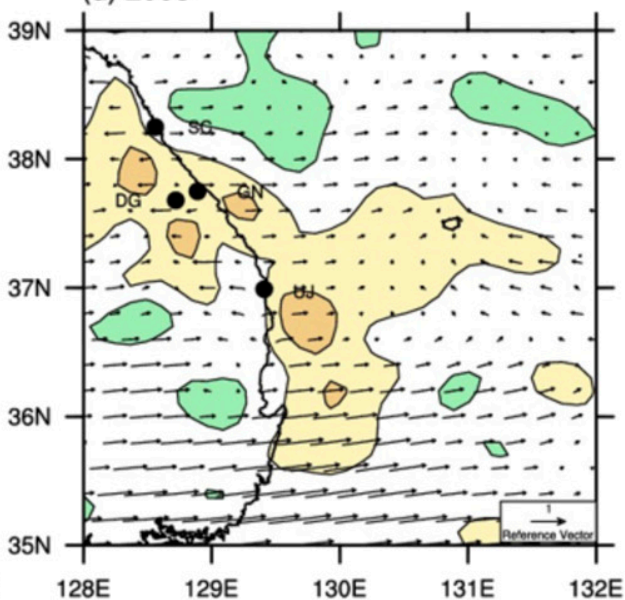

(f) 2014

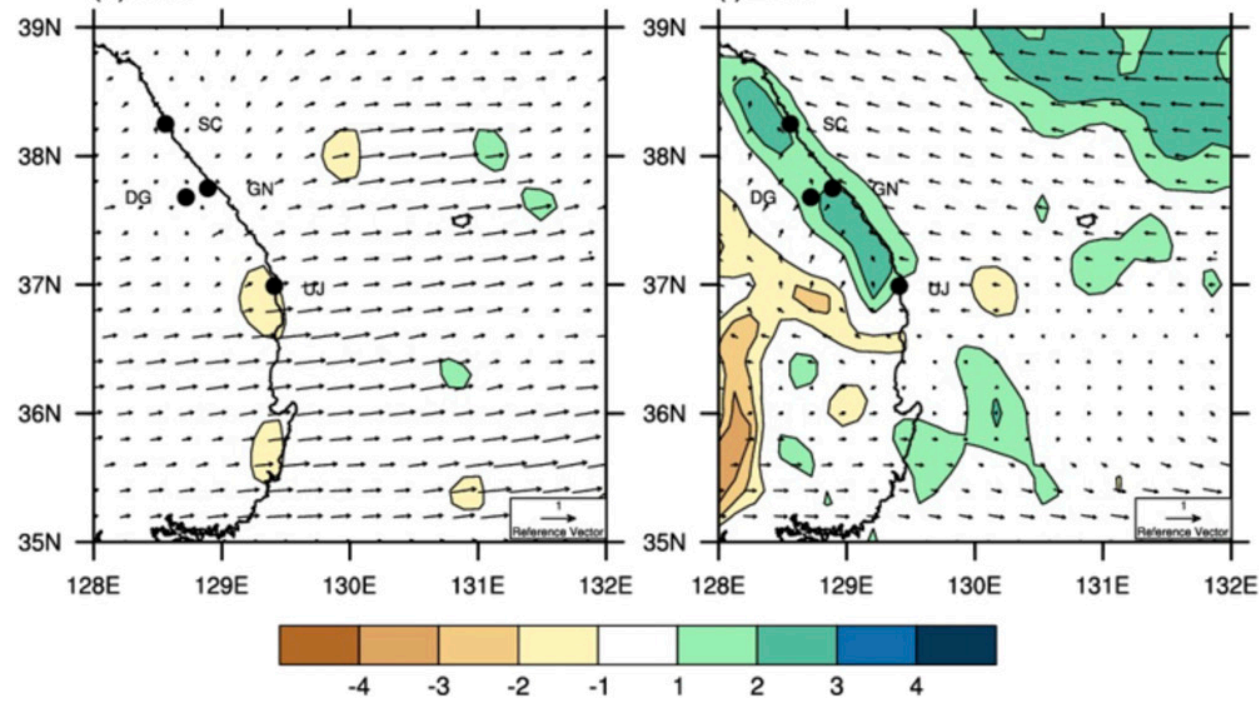

FIG. 12. As in Fig. 11, but for averaged moisture convergence (shaded; $10^{-6} \mathrm{~s}^{-1}$ ) and averaged moisture flux (vectors; $10^{-3} \mathrm{~m} \mathrm{~s}^{-1}$ ) at $850 \mathrm{hPa}$. 
the YD region. Despite the dominant easterly wind, in 2006 heavy snowfall could not occur over the YD region due to deficient moisture over the East Sea caused by the cold SST anomaly. Furthermore, the impact of local SST anomalies on snowfall amount is insignificant in 2007 because increased low-level moisture induced by warm SST anomaly cannot be transported to the YD region due to the unfavorable synoptic condition (i.e., westerly), which was dominant during most of January and February. In 2002, which is dominated by westerly winds, the difference between the CTL and CSST runs is relatively large due to the combination of easterly winds and warm SST anomalies during mid-January.

Wind and local SST anomalies can influence the vertical structure of the atmosphere over the YD region. Figure 13 shows vertical profiles of the difference in air temperature and water vapor between the CTL and CSST runs. The differences in air temperature and water vapor between the two runs, which are relatively large at low levels, propagate vertically to about $300 \mathrm{hPa}$. In the years with both warm SST anomalies and easterly anomalies, atmospheric temperature and water vapor at low levels are larger by $0.4-0.5 \mathrm{~K}$ and $0.01-0.02 \mathrm{~kg} \mathrm{~kg}^{-1}$, respectively, in the CTL run than the CSST run (Figs. 13a,b,f). These results indicate that the atmosphere becomes vertically unstable over the YD region. That is, a warm SST anomaly increases low-level air temperature and water vapor over the ocean through sensible heat and latent heat fluxes, and the warm moist air is transported to the YD region by the easterly wind. Therefore, in 1989, 1990, and 2014, when both the synoptic environment and SST conditions are satisfied, the CTL run simulates a warmer and moister lower troposphere over the YD region than does the CSST run. This warmer, moister lower troposphere induces heavy snowfall by increasing atmospheric instability and convective activity. As mentioned above, this is also the case during late January and mid-February in 2002, when warm SST anomaly and easterly occur together. In contrast, in 2006, the CTL run simulates decreased temperature and reduced moisture compared with CSST run, since cold and dry air induced by cold SST anomaly is moved to the YD region, which leads to a more stable atmosphere and less convection (Fig. 13d). In 2007, the differences in air temperature and water vapor are quite small due to the insufficient easterly inflow to the YD region (Fig. 13e).

\section{Summary and concluding remarks}

In this study, we investigate the relationships of snowfall variability over the YD region with the synoptic environment and local SST over the East Sea through analysis of 33 years of observational data and sensitivity experiments using a WRF-based RCM.

The interannual variabilities of the EAWM and snowfall amount over the YD region are negatively correlated (correlation coefficient of -0.45 ), but the interannual variabilities of the SST in the East Sea and snowfall amount are not significantly correlated (correlation coefficient is -0.06 ), despite the fact that SST plays a substantial role in intensifying snowfall. These relationships indicate that the interannual variability of snowfall over the YD region is more affected by the synoptic environment related to the EAWM than the local SST, and that the amount of snowfall over the YD region is not necessarily larger in years with warmer SST over the East Sea. Analyses of composite maps for strong and weak EAWM years demonstrate that the necessary conditions for heavier snowfall occur more frequently during the weak EAWM years than the strong EAWM years. During the weak EAWM years, a favorable synoptic environment (i.e., the surge of the Siberian high to the northeastern part of the Korean Peninsula and enhanced easterly winds into the YD region) can combine with favorable local SST conditions (i.e., warm SST anomalies, particularly offshore near the YD region) to produce larger snowfall amounts.

However, the observational analysis shows that snowfall amounts are not necessarily large during the weak EAWM years. The total accumulated amount of snowfall depends on the specifics of the synoptic environment and local SST condition. Snowfall amounts are particularly large when both the synoptic environment and local SST conditions are favorable at the same time. This elucidates that snowfall amount over the YD region is strongly related to the combined effects of the synoptic environment and local SST. Therefore, to investigate the impact of local SST on snowfall over the YD region, sensitivity experiments are conducted using an RCM. The sensitivity experiments compare a run with historical SST values to a run in which SST over the subregion $\left(35^{\circ}-39^{\circ} \mathrm{N}, 128^{\circ}-135^{\circ} \mathrm{E}\right)$ is set to the climatological mean. The sensitivity experiments confirm that when the synoptic environment is favorable, snowfall intensity over the YD region can be significantly affected by local SST over the East Sea. Correspondingly, local SST does not significantly impact snowfall amount if the synoptic environment is unfavorable. Warm SSTs can act as a source of energy for the formation of heavy snowfall, and SST regulates heat and moisture fluxes. Warm SST anomalies over the East Sea enhance latent heat fluxes from the ocean, leading to enhancements of low-level moisture convergence over the YD region, while cold SST anomalies lead to reduced latent heat fluxes and decreased moisture convergence. However, to produce heavy snowfall over the YD region, these processes must 

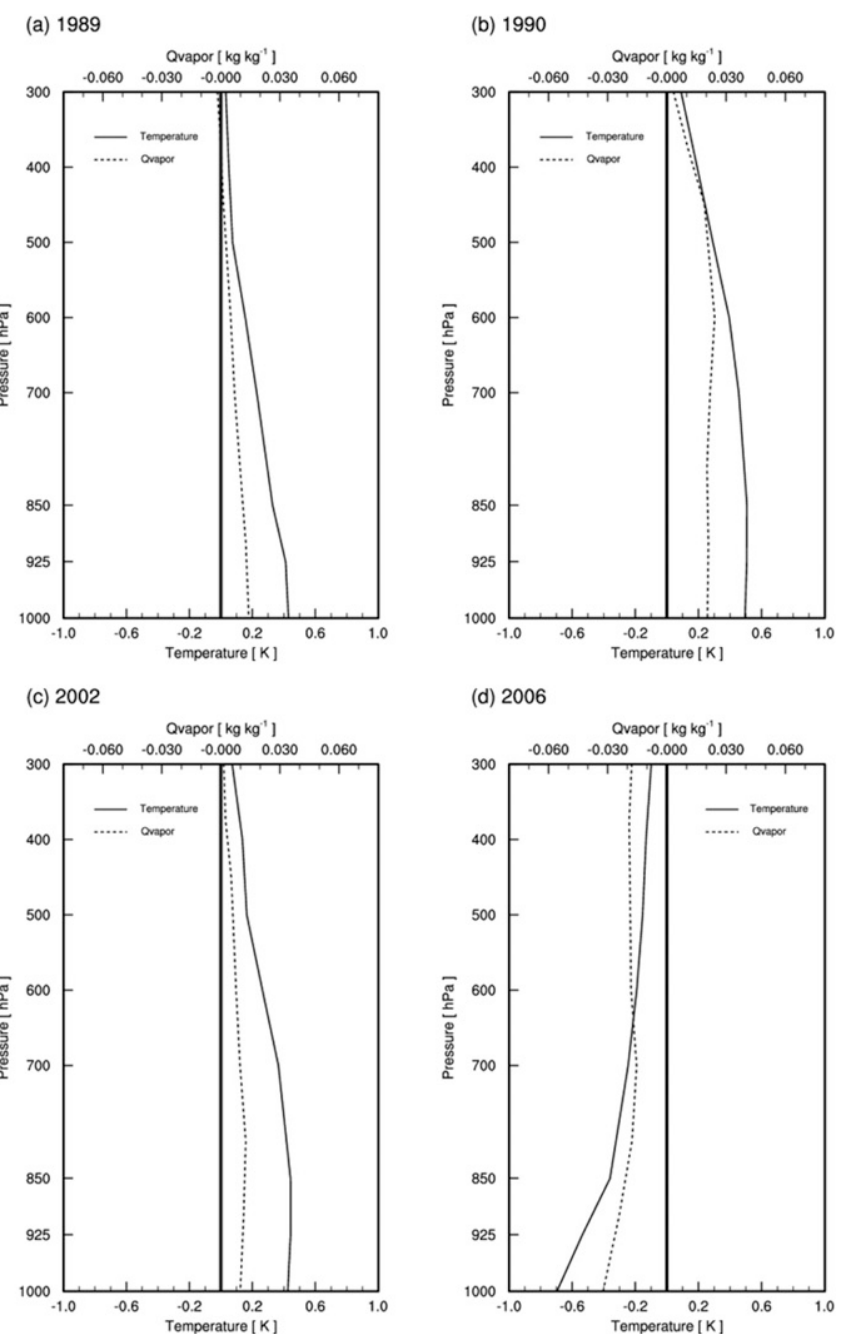

(d) 2006

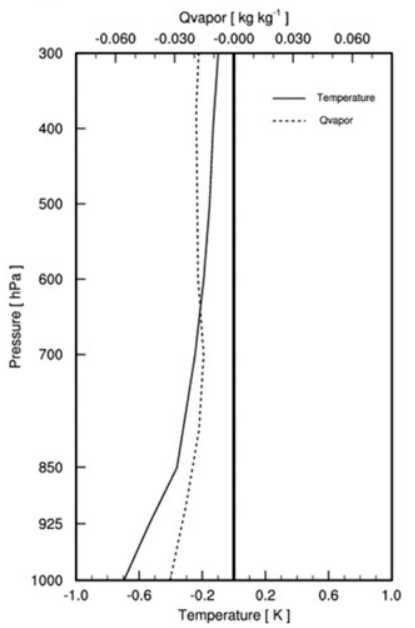

(e) 2007

(f) 2014
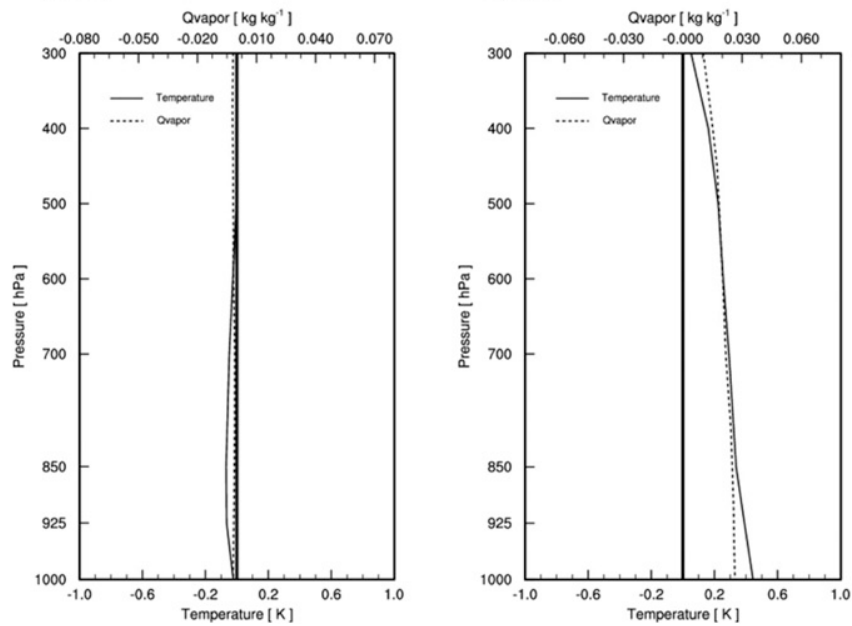

FIG. 13. Vertical profiles of differences in air temperature (solid line; $\mathrm{K}$ ) and water vapor (dashed line; $\mathrm{kg} \mathrm{kg}^{-1}$ ) over the YD region (averaged value of four stations) between CTL and CSST run (CTL minus CSST) for each weak EAWM year. 
be accompanied by a favorable synoptic environment. Without the surge of the Siberian high and the inflow of easterly winds, local SST does not have a significant impact on the amount of snowfall over the YD region.

This study confirms that severe snowfall over the YD region is very likely to occur during weak EAWM years if both the synoptic environment and the SST conditions are favorable, but that a warm SST anomaly alone does not necessarily increase snowfall over the YD region. However, the effect of local SST anomaly in the neutral EAWM years was more complex because the anomalies of synoptic environments were not distinct compared with the extreme EAWM years. For example, in 1996 and 1998 with positive snowfall anomalies, local SST anomalies were negative and positive, respectively. Also, an increasing trend of local SST could further complicate the relationships among the synoptic environment, local SST, and snowfall described here. An explanation of these complex relationships under a changing climate is needed. Also, our findings suggest that including the correct relationship among the EAWM, local SST, and heavy snowfall could lead to the improvements in medium- and long-range weather prediction, particularly predictions of heavy snowfall events in the Korean Peninsula.

Acknowledgments. This work was funded by the Korea Meteorological Administration Research and Development Program under Grant KMI (KMI2018-01211).

\section{REFERENCES}

Banzon, V., T. M. Smith, T. M. Chin, C. Liu, and W. Hankins, 2016: A long-term record of blended satellite and in situ sea-surface temperature for climate monitoring, modeling and environmental studies. Earth Syst. Sci. Data, 8, 165-176, https:// doi.org/10.5194/essd-8-165-2016.

Beljaars, A., 1995: The parametrization of surface fluxes in largescale models under free convection. Quart. J. Roy. Meteor. Soc., 121, 255-270, https://doi.org/10.1002/qj.49712152203.

Byun, K.-Y., J. Yang, and T.-Y. Lee, 2008: A snow-ratio equation and its application to numerical snowfall prediction. Wea. Forecasting, 23, 644-658, https://doi.org/10.1175/2007WAF2006080.1.

Cha, D.-H., C.-S. Jin, and D.-K. Lee, 2011a: Impact of local sea surface temperature anomaly over the western North Pacific on extreme East Asian summer monsoon. Climate Dyn., 37, 1691-1705, https://doi.org/10.1007/s00382-010-0983-z.

Cha, Y.-M., H.-W. Lee, and S.-H. Lee, 2011b: Impacts of the highresolution sea surface temperature distribution on modeled snowfall formation over the Yellow Sea during a cold-air outbreak. Wea. Forecasting, 26, 487-503, https://doi.org/ 10.1175/WAF-D-10-05019.1.

Chang, C., and K. Lau, 1982: Short-term planetary-scale interactions over the tropics and midlatitudes during northern winter. Part I: Contrasts between active and inactive periods. Mon. Wea. Rev., 110, 933-946, https://doi.org/10.1175/15200493(1982)110<0933:STPSIO > 2.0.CO;2.
_ J. Erickson, and K. Lau, 1979: Northeasterly cold surges and near-equatorial disturbances over the winter MONEX area during December 1974. Part I: Synoptic aspects. Mon. Wea. Rev., 107, 812-829, https://doi.org/10.1175/1520-0493(1979) $107<0812$ :NCSANE $>2.0$.CO;2.

Chen, F., and J. Dudhia, 2001: Coupling an advanced land surfacehydrology model with the Penn State-NCAR MM5 modeling system. Part I: Model implementation and sensitivity. Mon. Wea. Rev., 129, 569-585, https://doi.org/10.1175/1520-0493(2001) 129<0569:CAALSH > 2.0.CO;2.

Chen, W., H. Graf, and R. Huang, 2000: The interannual variability of East Asian winter monsoon and its relation to the summer monsoon. Adv. Atmos. Sci., 17, 48-60, https://doi.org/10.1007/ s00376-000-0042-5.

Chen, Z., R. Wu, and W. Chen, 2015: Effects of northern and southern components of the East Asian winter monsoon variability on SST changes in the western North Pacific. J. Geophys. Res., 120, 3888-3905, https://doi.org/10.1002/2015JD023149.

Cho, K.-H., and T.-Y. Kwon, 2012: Orographic and ocean effects associated with a heavy snowfall event over Yeongdong region. Atmosphere, 22, 57-71, https://doi.org/10.14191/Atmos.2012.22.1.057.

Cho, Y.-J., T.-Y. Kwon, and B.-C. Choi, 2015: Characteristics of meteorological variables in the leeward side associated with the downslope windstorm over the Yeongdong region. J. Korean Earth Sci. Soc., 36, 315-329, https://doi.org/10.5467/ JKESS.2015.36.4.315.

Choi, G.-Y., and J.-S. Kim, 2010: Surface synoptic climatic patterns for heavy snowfall events in the republic of Korea. J. Korean Geogr. Soc., 45, 319-341.

Chung, K., J. Kim, and T. Kwon, 2004: Characteristics of lowertropospheric wind related with winter precipitation in the Yeongdong region. J. Korean Meteor. Soc., 40, 369-380.

Cohen, A. E., S. M. Cavallo, M. C. Coniglio, and H. E. Brooks, 2015: A review of planetary boundary layer parameterization schemes and their sensitivity in simulating southeastern U.S. cold season severe weather environments. Wea. Forecasting, 30, 591-612, https://doi.org/10.1175/WAF-D-14-00105.1.

Dee, D. P., and Coauthors, 2011: The ERA-Interim reanalysis: Configuration and performance of the data assimilation system. Quart. J. Roy. Meteor. Soc., 137, 553-597, https://doi.org/ 10.1002/qj.828.

Ding, Y., and T. N. Krishnamurti, 1987: Heat budget of the Siberian high and the winter monsoon. Mon. Wea. Rev., 115, 2428-2449, https:// doi.org/10.1175/1520-0493(1987)115<2428:HBOTSH>2.0.CO;2.

Dudhia, J., 1989: Numerical study of convection observed during the winter monsoon experiment using a mesoscale twodimensional model. J. Atmos. Sci., 46, 3077-3107, https://doi.org/ 10.1175/1520-0469(1989)046<3077:NSOCOD > 2.0.CO;2.

Fernández-González, S., F. Valero, J. Sánchez, E. Gascón, L. López, E. García-Ortega, and A. Merino, 2015: Numerical simulations of snowfall events: Sensitivity analysis of physical parameterizations. J. Geophys. Res. Atmos., 120, 10130 10148 , https://doi.org/10.1002/2015JD023793.

Fu, J., W. Qian, X. Lin, and D. Chen, 2008: Trends in graded precipitation in China from 1961 to 2000. Adv. Atmos. Sci., 25, 267-278, https://doi.org/10.1007/s00376-008-0267-2.

Han, S.-H., and J. G. Lee, 2007: A numerical simulation study on the sensitivity of WRF model in the wind field to the steepness of mountain slopes. Atmosphere, 17, 349-364.

Jhun, J.-G., and E.-J. Lee, 2004: A new East Asian winter monsoon index and associated characteristics of the winter monsoon. J. Climate, 17, 711-726, https://doi.org/10.1175/1520-0442(2004) 017<0711:ANEAWM >2.0.CO;2. 
D.-K. Lee, and H.-A. Lee, 1994: A study on the heavy snowfalls occurred in South Korea. J. Korean Meteor. Soc., 30, 97-117.

Jung, S.-H., E.-S. Im, and S.-O. Han, 2012: The effect of topography and sea surface temperature on heavy snowfall in the Yeongdong region: A case study with high resolution WRF simulation. Asia-Pac. J. Atmos. Sci., 48, 259-273, https:// doi.org/10.1007/s13143-012-0026-2.

Jung, S.-P., Y.-K. Lim, K.-H. Kim, S.-O. Han, and T.-Y. Kwon, 2014: Characteristics of precipitation over the east coast of Korea based on the special observation during the winter season of 2012. J. Korean Earth Sci. Soc., 35, 41-53, https:// doi.org/10.5467/JKESS.2014.35.1.41.

Kain, J. S., 2004: The Kain-Fritsch convective parameterization: An update. J. Appl. Meteor., 43, 170-181, https://doi.org/ 10.1175/1520-0450(2004)043<0170:TKCPAU > 2.0.CO;2.

Kang, S.-D., and J.-B. Ahn, 2008: Numerical study on the formation and maintenance mechanisms of cloud street in the East Sea during cold air outbreak. Asia-Pac. J. Atmos. Sci., 44, 105119.

Kim, J.-E., T.-Y. Kwon, and B.-Y. Lee, 2005: Characteristics of sensible heat and latent heat fluxes over the East Sea related with Yeongdong heavy snowfall events. Ocean Polar Res., 27, 237-250, https://doi.org/10.4217/OPR.2005.27.3.237.

Kim, J.-H., and I.-U. Chung, 2006: Study on mechanisms and orographic effect for the springtime downslope windstorm over the Yeongdong region. Atmosphere, 16, 67-83.

Kim, T., and E. K. Jin, 2016: Impact of an interactive ocean on numerical weather prediction: A case of a local heavy snowfall event in eastern Korea. J. Geophys. Res. Atmos., 121, 82438253, https://doi.org/10.1002/2016JD024763.

Kristovich, D. A., and M. L. Spinar, 2005: Diurnal variations in lake-effect precipitation near the western Great Lakes. $J$. Hydrometeor., 6, 210-218, https://doi.org/10.1175/JHM403.1.

Lee, D.-K., D.-H. Cha, C.-S. Jin, and S.-J. Choi, 2013: A regional climate change simulation over East Asia. Asia-Pac. J. Atmos. Sci., 49, 655-664, https://doi.org/10.1007/s13143-013-0058-2.

Lee, H., and T.-Y. Lee, 1994: The governing factors for heavy snowfalls in Youngdong area. Asia-Pac. J. Atmos. Sci., 30, 197-218.

Lee, H.-Y., H.-Y. Ko, K.-E. Kim, and I.-H. Yoon, 2010: An analysis of characteristics of heavy rainfall events over Yeongdong region associated with tropopause folding. J. Korean Earth Sci. Soc., 31, 354-369, https://doi.org/10.5467/JKESS.2010.31.4.354.

Lee, J. G., and Y. J. Kim, 2008: A numerical case study examining the orographic effect of the Taebaek mountains on snowfall distribution over the Yeongdong area. Atmosphere, 18, 367386.

, and - 2009: A numerical case study examining the orographic effect of the northern mountain complex on snowfall distribution over the Yeongdong region. Atmosphere, 19, 345370.

Lee, J.-S., T.-Y. Kwon, and D.-R. Kim, 2006: Statistical verification of precipitation forecasts from MM5 for heavy snowfall events in Yeongdong region. Atmosphere, 16, 125-139.

Lee, S.-H., and C.-S. Ryu, 2010: Influence of continuous satellitebased SST distribution on heavy snowfall events over the Korean Peninsula. Int. J. Remote Sens., 31, 2853-2883, https:// doi.org/10.1080/01431160903140795.
Lin, Y.-L., R. D. Farley, and H. D. Orville, 1983: Bulk parameterization of the snow field in a cloud model. J. Climate Appl. Meteor., 22, 1065-1092, https://doi.org/10.1175/1520-0450(1983) 022<1065:BPOTSF $>2.0 . \mathrm{CO} ; 2$.

Lu, M.-M., and C.-P. Chang, 2009: Unusual late-season cold surges during the 2005 Asian winter monsoon: Roles of Atlantic blocking and the central Asian anticyclone. J. Climate, 22, 5205-5217, https://doi.org/10.1175/2009JCLI2935.1.

Miles, N. L., and J. Verlinde, 2005: Observations of transient linear organization and nonlinear scale interactions in lake-effect clouds. Part I: Transient linear organization. Mon. Wea. Rev. 133, 677-691, https://doi.org/10.1175/MWR-2879.1.

Mlawer, E. J., S. J. Taubman, P. D. Brown, M. J. Iacono, and S. A. Clough, 1997: Radiative transfer for inhomogeneous atmospheres: RRTM, a validated correlated- $k$ model for the longwave. J. Geophys. Res., 102,16 663-16 682, https://doi.org/ 10.1029/97JD00237.

Murakami, T., 1987: Effects of the Tibetan Plateau. Monsoon Meteorology, C. P. Chang and T. N. Krishnamurty, Eds., Oxford University Press, 235-270.

Ninomiya, K., T. Nishimura, T. Suzuki, and S. Matsumura, 2006: Polar-air outbreak and air-mass transformation over the east coast of Asia as simulated by an AGCM. J. Meteor. Soc. Japan, 84, 47-68, https://doi.org/10.2151/jmsj.84.47.

Pleim, J. E., 2007: A combined local and nonlocal closure model for the atmospheric boundary layer. Part I: Model description and testing. J. Appl. Meteor. Climatol., 46, 1383-1395, https:// doi.org/10.1175/JAM2539.1.

Reynolds, R. W., T. M. Smith, C. Liu, D. B. Chelton, K. S. Casey, and M. G. Schlax, 2007: Daily high-resolution-blended analyses for sea surface temperature. J. Climate, 20, 5473-5496, https://doi.org/10.1175/2007JCLI1824.1.

Skamarock, W. C., and Coauthors, 2008: A description of the Advanced Research WRF version 3. NCAR Tech. Note NCAR/ TN-475+STR, 113 pp., https://doi.org/10.5065/D68S4MVH.

Takahashi, H. G., N. N. Ishizaki, H. Kawase, M. Hara, T. Yoshikane, X. Ma, F. Kimura, 2013: Potential impact of sea surface temperature on winter precipitation over the Japan Sea side of Japan: A regional climate modeling study. J. Meteor. Soc. Japan, 91, 471-488, https://doi.org/10.2151/ jmsj.2013-404.

Wu, B., and J. Wang, 2002: Winter Arctic oscillation, Siberian high and East Asian winter monsoon. Geophys. Res. Lett., 29, 1897 https://doi.org/10.1029/2002GL015373.

Xin, X., R. Yu, T. Zhou, and B. Wang, 2006: Drought in late spring of South China in recent decades. J. Climate, 19, 3197-3206, https://doi.org/10.1175/JCLI3794.1.

Yu, L., X. Jin, and R. A. Weller, 2008: Multidecade Global Flux Datasets from the Objectively Analyzed Air-Sea Fluxes (OAFlux) Project: Latent and sensible heat fluxes, ocean evaporation, and related surface meteorological variables. OAFlux Project Tech. Rep. OA-2008-01, 64 pp.

Zhou, B., and H. Wang, 2008: Interdecadal change in the connection between Hadley circulation and winter temperature in East Asia. Adv. Atmos. Sci., 25, 24-30, https://doi.org/10.1007/ s00376-008-0024-6.

Zhou, L. T., 2011: Impact of East Asian winter monsoon on rainfall over southeastern China and its dynamical process. Int. J. Climatol., 31, 677-686, https://doi.org/10.1002/joc.2101. 